\title{
A aquisição de acervo no Museu Paulista (1990-2015)
}

The collection's acquisition at Paulista Museum (1990-2015)

https://doi.org/10.1590/1982-02672020v28e21

\section{LEONARDO DA SILVA VIEIRA'}

https://orcid.org/0000-0002-1278-7168

Universidade de São Paulo /São Paulo, SP, Brasil

RESUMO: Este artigo, baseado na dissertação recentemente defendida pelo autor, apresenta considerações sobre a política e a prática de aquisição de acervo museológico no Museu Paulista durante o período de 1990 a 2015. A atual política de acervo da instituição foi implementada durante a gestão do professor Ulpiano Toledo Bezerra de Meneses no âmbito do plano diretor da instituição. Este documento foi fundamental por estabelecer definitivamente a atuação do museu no campo da História e Cultura Material, bem como por vincular a aquisição de acervo às linhas de pesquisa da instituição.

PALAVRAS-CHAVE: Museu Paulista. Política de acervo. Musealização.

ABSTRACT: This paper, based on the dissertation recently defended by the author, presents considerations about the politics and the practice of acquisition of museum collection in the Paulista Museum during the period from 1990 to 2015. The current collection policy of the institution was implemented during the administration of Professor Ulpiano Toledo Bezerra de Meneses in the Master Plan of the institution. This document was fundamental for definitively establishing the Museum's performance in the field of History and Material Culture, as well as linking the acquisition of collections to the research lines of the institution.

KEYWORDS: Museu Paulista. Acquisition's policy. Musealization.

\begin{abstract}
1. Bacharel em História pela Faculdade de Filosofia, Letras e Ciências Humanas da Universidade de São Paulo e mestre em Museologia pelo Programa de Pós-Graduação Interunidades em Museologia da USP, atualmente trabalha como pesquisador no Memorial da Inclusão e coordena e desenvolve projetos culturais ligados à memória, cultura e patrimônio em bairros da zona leste da cidade de São Paulo por meio do Coletivo Memória \& Resistência. E-mail: <leonardo. silva.vieira@alumni.usp.br>.
\end{abstract}


2. Cf. Alves (2001).

3. Cf. Brefe (2005).

4. Ulpiano Toledo Bezerra de Meneses, antes de assumir a direção do Museu Paulista, integrou a comissão responsável pela discussão sobre o conceito de curadoria científica e seu papel no âmbito dos museus universitários enquanto relator da atuação institucional do Museu Paulista. Essa comissão foi instituída pela Universidade de São Paulo em 1986, por meio da Portaria GR 2073, e deve ser entendida como parte de um importante processo de estudo e regulamentação dos museus estatutários - a saber, Museu Paulista, Museu de Arte Contemporânea, Museu de Zoologia e Museu de Arqueologia e Etnologia - por parte da Reitoria da Universidade ao longo dos anos de 1980 e 1990. Cf. Abreu (2011); Brandão; Costa (2007); Processos $\mathrm{n}^{\circ}$ 89.1.3376.1.0, 85.1.32549.1.2, 89.1 .3376 .1 .0 , $91.1 .46592 .1 .9 \quad \mathrm{e}$ 91.1.6571.1.0/Arquivo Geral da USP).

5. Barbuy; Ornstein (2015, p. 263).

6. Padilha (2014, p. 26).

\section{INTRODUÇÃO}

Museu Paulista da Universidade de São Paulo (MP-USP) foi um dos primeiros museus criados no Brasil. Abrigado no edifício-monumento em prol da Independência do Brasil, o museu, dedicado essencialmente às ciências naturais, foi aberto em 1895 sob a direção do zoólogo Herman von thering. Ao longo de sua trajetória, porém, a instituição foi direcionada para o campo de estudos da História e da Cultura Material. ${ }^{2}$

Tal direcionamento iniciou-se já nas primeiras décadas do século XX, a partir da transferência de acervo de caráter biológico para outras instituições. Com a nomeação do historiador de ofício Afonso d'Escragnolle Taunay, em 1917, para a direção do museu por ocasião das comemorações do centenário da Independência, a História tornou-se gradativamente a disciplina científica primordial para a atuação institucional. ${ }^{3}$

A conclusão desse processo de redirecionamento do Museu Paulista foi possível graças ao plano diretor da instituição, implementado por seu atual diretor à época, o historiador Ulpiano Toledo Bezerra de Meneses, em 1990.4 Esse documento, responsável por uma espécie de "reorganização conceitual e uma racionalização", 5 determinou definitivamente a atuação do museu no campo da História e da Cultura Material alinhada aos preceitos científicos, técnicos e sociais contemporâneos.

O plano diretor do Museu Paulista estabeleceu também seu atual programa de acervos, o qual inclui sua política de aquisição de acervos museológicos. Essa tipologia de documento, segundo Renata Cardoso Padilha, "apresenta, em linhas gerais, as bases que definem o acervo do museu, tendo em vista sua diversidade tipológica, sua temática central e as formas e possibilidades de expansão". ${ }^{6}$

Desse modo, o programa de acervo se ocupa das questões relacionadas a aquisição, documentação, conservação, guarda, restauro e descarte do acervo museológico. Esse documento é de fundamental importância, pois nele estão contidos os direcionamentos relativos aos acervos, tendo como base, essencialmente, os propósitos e finalidades de cada instituição.

A atual política de acervo do Museu Paulista, além de enfatizar a importância da documentação das coleções e de um banco de dados que referencie outras coleções, estabelece que:

A especificidade do museu deriva do acervo, mas a especificidade do acervo deve derivar não de qualquer propósito taxonômico, mas de uma determinada problemática científica (no caso, histórica), que tal acervo permite cobrir. Por esta razão, o acervo tem que ter organicidade, coerência e amplitude e incluir, não "objetos históricos", obrigatoriamente marcados por atributos particulares, mas quaisquer suportes materiais de informação pertinen- 
tes aos problemas históricos em causa. Daí porque a ampliação do acervo do Museu Paulista deverá ser desenvolvida apenas nos quadros da pesquisa em torno dos três eixos propostos (item 3) e terá que assumir postura ativa, quer na coleta de campo, quer na indução de doações (com a caracterização explícita das categorias de interesses institucional). ${ }^{7}$

O trecho acima permite diversas considerações sobre a política de aquisição de acervo da instituição. Destaco apenas duas: primeiramente, é interessante notar que no Museu Paulista a incorporação de coleções ao acervo institucional, seja por meio de pesquisa de campo ou doações, deve respeitar o vínculo de tais coleções aos temas de pesquisa do museu. Essa postura mostra-se totalmente condizente para uma instituição vinculada ao aparato universitário, bem como de sólida trajetória no âmbito da pesquisa desde sua fundação.

Em seguida, gostaria de ressaltar o fato do Museu Paulista considerar "quaisquer suportes materiais de informação" como objeto digno de ser musealizado. ${ }^{8}$ Ao propor tal concepção, o museu afasta-se de uma noção positivista da História, ${ }^{9}$ que privilegia eventos e figuras de exceção, e caminha em direção à uma prática historiográfica atenta aos mais diversos âmbitos da vida social e às múltiplas manifestações da cultura material das sociedades.

A predisposição da instituição em abarcar na narrativa historiográfica diversas esferas sociais, por exemplo, encontra lastro em importantes movimentos intelectuais, políticos e culturais presentes no debate público à época, como, por exemplo, os movimentos da Nova História e da Nova Museologia. De modo geral, tais correntes de pensamento procuravam alargar os objetos de estudo da História e da Museologia, respectivamente, bem como desenvolver posturas metodológicas que tornassem as narrativas construídas no âmbito destes dois campos do conhecimento mais plurais e complementares. ${ }^{10}$

Outro sinal da influência desses dois movimentos para o plano diretor da instituição apresenta-se nos "segmentos da cultura material considerados prioritários [...] além de estratégicos" para o trabalho desenvolvido no MP, ou seja, as três linhas de pesquisa do museu:

$$
\begin{aligned}
& \text { | - Quotidiano e sociedade (papéis sexuais, etários e enculturação) } \\
& \text { |I - Universo do trabalho (pré e proto-industrial) } \\
& \text { III - Imaginário (os vetores materiais do sentido) }{ }^{11}
\end{aligned}
$$

Estes três segmentos procuram abarcar âmbitos diversos da vida social e tiveram seus estudos incentivados por boa parte dos historiadores alinhados
7. Meneses (1990, p. 3-4).

8. O conceito de musealização é aqui entendido como o processo de transformação do objeto em documento e sua comunicação. Tal processo é constituído, grosso modo, pelas etapas de aquisição, pesquisa, conservação, documentação e comunicação - Cury (2005, p. 25-26).

9. Em linhas gerais, entende-se como história positivista a historiografia produzida com base na noção de que caberia aos historiadores narrar os fatos do passado tais como ocorreram, relativos à eventos e personagens excepcionais e baseando-se em documentos oficiais.

10. Cf. Almeida (1996); Barros (2010); Burke (1992); Cury (2003).

11. Meneses (1989, p. 3). 
12. Cf. Barros (2011); Cardoso; Vainfas (1997). ao movimento da Nova História, principalmente os estudos relativos à dinâmica do imaginário. ${ }^{12}$ De toda forma, como já dito anteriormente, as três temáticas acima foram desenhadas para guiar a prática institucional e, consequentemente, a política de aquisição de acervo museológico.

Após esta breve explanação sobre o conteúdo essencial da atual política de acervo do museu, veremos no próximo tópico como se deu a prática de aquisição de acervo na instituição, seja por doação ou compra. Cabe dizer que as considerações apresentadas foram fundamentadas tanto nos processos de aquisição por compra e nas cartas de doação de acervo quanto nos relatórios institucionais anuais.

\section{A AQUISIÇÃO DE ACERVO EM NÚMEROS}

Nesta seção, será apresentado um panorama quantitativo dos dados obtidos a partir da análise da documentação relativa aos processos de aquisição de acervo por compra e doação no Museu Paulista. De início, é importante relatar que foram localizados 617 processos de aquisição, sendo 509 processos por doação e 108 por compra direta.

Nos gráficos abaixo podemos notar a distribuição dos processos pelos anos de abrangência desta pesquisa. Com relação aos processos de aquisição por doação (gráfico 1), cabe ressaltar o expressivo crescimento das doações a partir de 1992, atingindo-se picos nos anos de 1999 e 2005. Em 2006, o número de doações cai drasticamente, mantendo-se até 2010 em menos de 15 doações por ano.

Sobre os processos de aquisição por compra direta, deve-se primeiramente abordar o fato de que se mostram, quando comparados com os dados das aquisições por doação, bem reduzidos. Tal situação se explica por inúmeras razões, das quais destaco duas: a aquisição por compra direta demanda, do Museu Paulista, maior investimento financeiro e em recursos humanos para que a pesquisa de campo e, consequentemente, a aquisição se efetue; em segundo lugar, muitas das aquisições por compra abarcam grandes conjuntos de documentos.

Em seguida, vale a pena ressaltar que o gráfico de aquisição por compra apresenta forte caráter oscilante com relação aos processos. Além do ano 2011 , para o qual foram localizadas 11 referências a processos de aquisição, nos outros anos, em média, foram iniciados 2,6 processos. 
Número anual de processos de aquisição de acervo por doação (1990-2015)

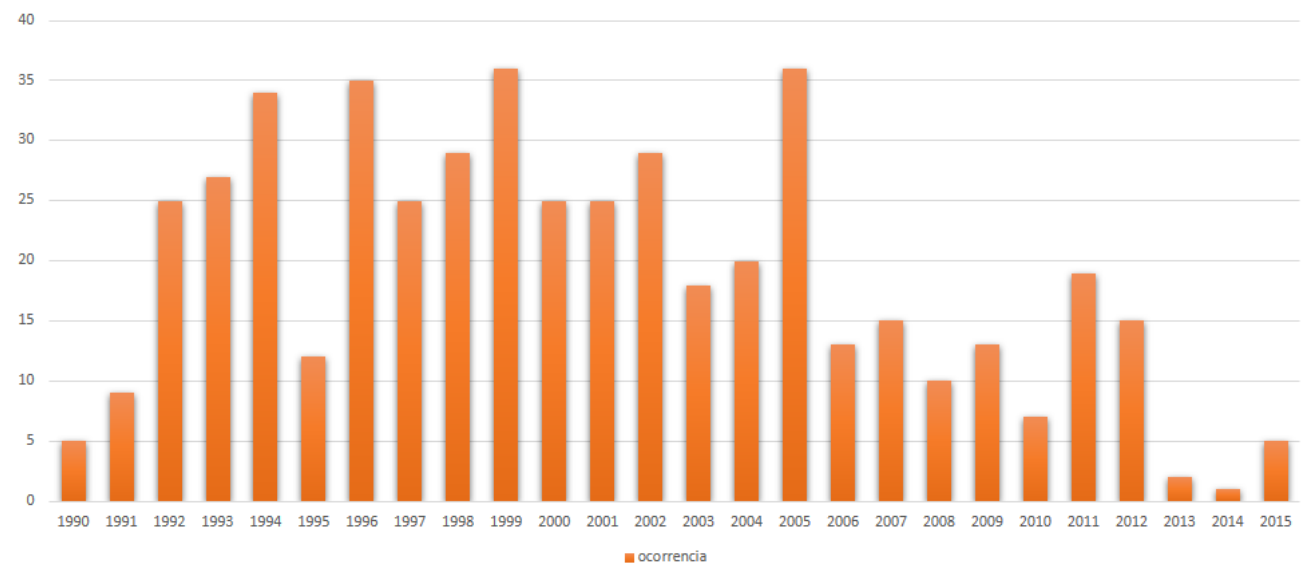

Gráfico 1 - Número anual de processos de aquisição de acervo por doação (1990-20 1 5). Fonte: Vieira, 2018.

Número anual de processos de aquisição de acervo por compra (1990-2015) 12

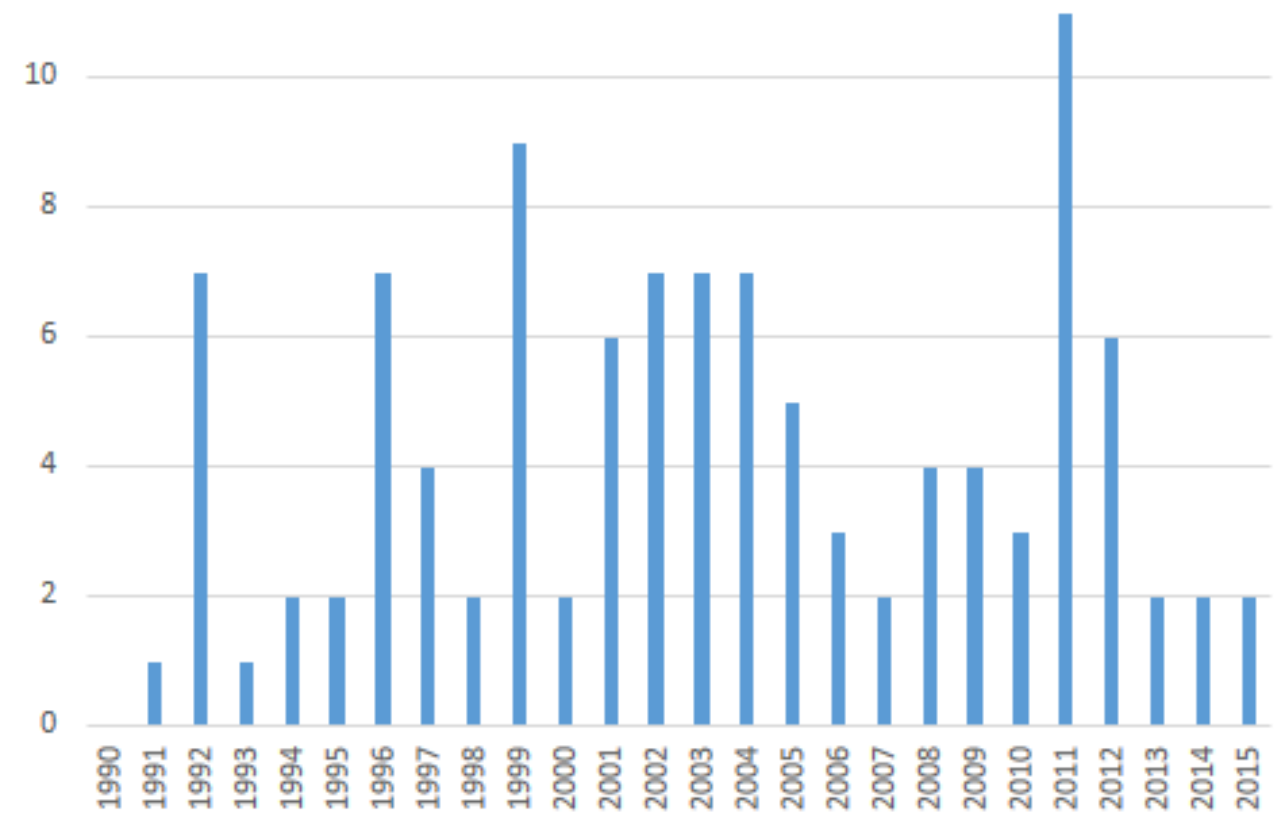

Gráfico 2 -Número anual de processos de aquisição por compra (1990-2015). Fonte: Vieira, 2018. 
13. Para acesso à documentação das doações realizadas pelo Museu de Zoologia da USP, Museu de Santo André e o Instituto Borges de Artes e Ofícios de Itu, cf. as cartas de doações dos anos 1993 , 1995, 1991 e 2005/SVDHICO-MP, respectivamente.
Um segundo elemento importante para a análise das aquisições de acervo no Museu Paulista refere-se ao perfil dos doadores e fornecedores de acervo à instituição. Os dados das doações (gráfico 3) demonstram que estas iniciativas são efetuadas, na sua imensa maioria, por pessoas físicas - 93\%. Este é um forte elemento para considerarmos que a instituição constitui referência para a salvaguarda cultural para parcelas consideráveis da sociedade civil.

É importante citar que 25\% dos doadores realizaram mais de uma doação durante o período compreendido por esta pesquisa. Há casos de sujeitos que efetuaram mais de dez doações, porém, em média, ocorreram de quatro a cinco doações efetuadas pelos mesmos sujeitos.

Cabe destacar também que, mesmo que em escala muito menor, há casos de doações praticadas por pessoas jurídicas. Estas, aliás, são em sua maioria instituições congêneres ao Museu Paulista: foram localizadas doações efetuadas pelo Centro de Documentação e Informação Científica da Pontifícia Universidade Católica de São Paulo (CEDIC - PUC SP), pelo Museu de Zoologia da USP, Museu de Arte Moderna de São Paulo (MAM-SP), Museu de Santo André, Instituto Borges de Artes e Ofícios de ltu e Museu Frei Galvão. ${ }^{13}$

\section{Tipologia dos doadores (1990-2015)}

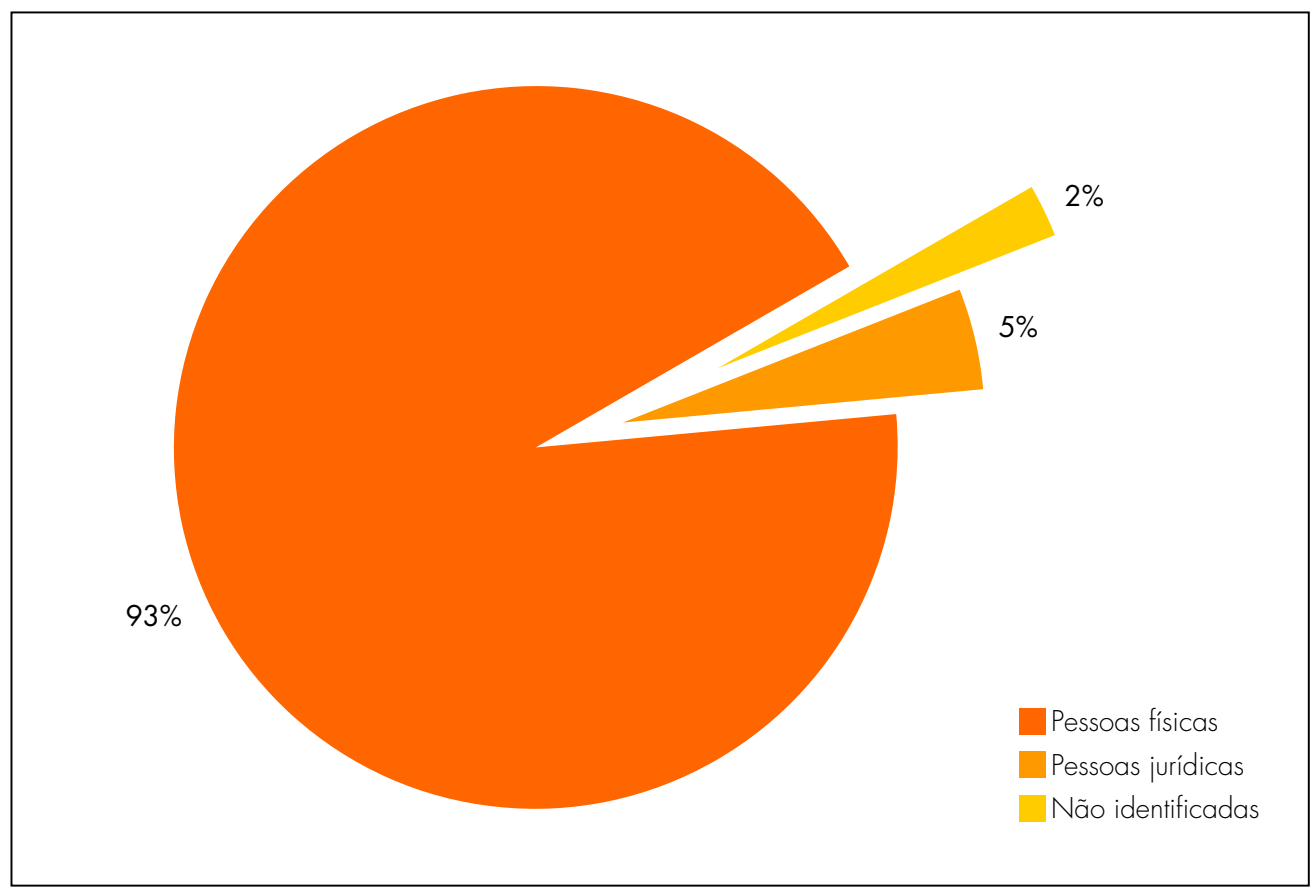

Gráfico 3 - Gráfico acerca da tipologia dos doadores (1990-2015). Fonte: Vieira, 2018. 
É interessante notarmos a existência desse tipo de relação do Museu Paulista com outras instituições museológicas e centros de documentação, pois nos indica um forte processo de especialização e enriquecimento dos acervos institucionais. É notório na documentação consultada que muitas das doações feitas por essas instituições foram realizadas pelo entendimento de que tais itens estão mais bem alinhados à atuação do Museu Paulista, levando-se a afirmar que as instituições estão mais preocupadas em possuir acervos que se relacionem diretamente com sua missão e propósitos. ${ }^{14}$

Sobre o perfil dos fornecedores de acervo, pode-se dizer que, em geral, mantém-se o padrão do perfil dos doadores. No caso das aquisições por compra direta, porém, há uma diferença menor no número de aquisições efetuadas de pessoas jurídicas e pessoas físicas.

\section{Tipologia dos fornecedores de acervo por compra (1990-2015)}

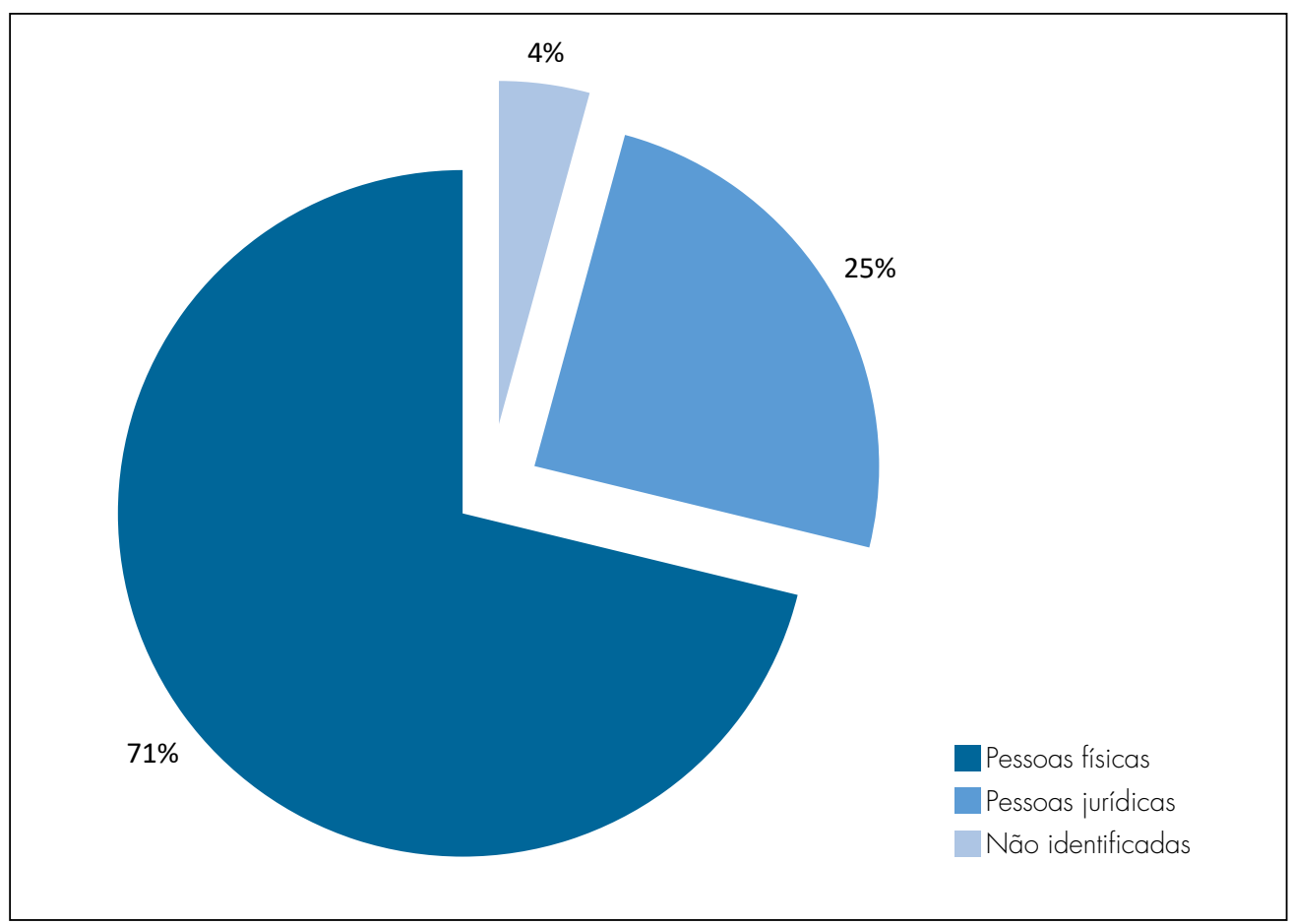

Gráfico 4 - Gráfico acerca da tipologia dos fornecedores de acervo por compra (1990-2015). Fonte: Vieira, 2018.

Outra característica fundamental deve ser salientada: diversamente do que ocorre com as doações - nas quais as pessoas jurídicas doadoras são em sua maioria instituições congêneres ao MP - as pessoas jurídicas que constam
14. Como exemplo, pode-se citar trecho da carta de doação do Museu de Arte Moderna referente a um conjunto de peças de vestuário: "Chegou ao nosso conhecimento que o Museu Paulista estaria interessado em receber doações de peças de vestuário. O Museu de Arte Moderna detém uma coleção de roupas que nos foi doada em gestão anterior e que gostaríamos de oferecer a outro Museu por estar em desacordo com o nosso acervo. Segue anexo a lista das peças, provenientes de famílias paulistas e datando das últimas décadas deste século (anos 60, 70 aproximadamente)" (Carta de doação do MAM-SP, 1993/SVDHICO-MP). Neste documento está nitidamente expresso o anseio do MAM-SP em legar para outras instituições itens de seu acervo que se encontram em desacordo com sua política de acervo. 
15. É de fundamental importância explicar que os gráficos referentes às tipologias de acervo e às vinculações com linhas e projetos de pesquisa apresentam marcadores diferentes para o mesmo processo de aquisição de acervo. Diferentemente do que é feito no Museu Paulista, esta pesquisa procurou considerar um mesmo conjunto documental como alusivo à variadas temáticas $\mathrm{e}$ tipologias. Por exemplo: um objeto, tal como uma medalha, pode ser classificado como Medalhística, ao mesmo tempo em que se encaixa também como um objeto comemorativo. como fornecedoras de acervo ao Museu Paulista são lojas de artigos de antiquário $(44,82 \%)$ e o Clube da Medalha $(55,17 \%)$.

É importante evidenciarmos os dados acima pois eles nos levam a refletir sobre a relação estabelecida entre o Museu Paulista e o mercado de antiguidades. Essa relação, de acordo com a documentação consultada, encontra-se firmada há longo prazo e efetiva-se por intermédio de transações comerciais do Museu com pessoas jurídicas e com pessoas físicas com atuação conhecida no mercado de antiquariato. Nas próximas páginas voltarei a este tópico.

Atentemo-nos, agora, para a tipologia de acervo presente nos conjuntos adquiridos por doação e compra direta. No geral, as duas modalidades de aquisição de acervo abarcam itens de variadas tipologias, ou seja, desde objetos de caráter excepcional - por sua procedência e constituição física - até objetos de uso cotidiano.

O gráfico a seguir (gráfico 5) apresenta as diversas tipologias e categorias de objetos incorporados ao acervo do Museu Paulista por meio das doações. Como podemos notar, as tipologias que mais receberam acréscimos em sua constituição referem-se aos acervos de indumentária (1 13 processos - 22,20\%), fotografia 197 processos - 19,05\%) e documentos pessoais (76 processos $-14,93 \%$ ), seguidos de artes $(43 \text { processos }-8,44 \% \text { ) e cartões-postais (42 processos }-8 \%)^{15}$

Cabe destacar também que tipologias tradicionais em museus de história encontram espaço bem reduzido no rol das doações recebidas pelo Museu Paulista. Objetos ligados a práticas religiosas, militares, artísticas, filatélicas, medalhísticas e comemorativas, por exemplo, correspondem apenas a $14 \%$ dos processos.

Já o gráfico 6 apresenta as categorias de acervo incorporadas pelo Museu Paulista por meio de compra direta. De maneira decrescente, podemos notar que as fotografias (26 processos $-24,07 \%$ ), os objetos relacionados ao campo da Medalhística e da Heráldica (22 processos - 20,37\%), utensílios de cozinha (21 processos - 19,44\%), cartões-postais (17 processos - 15,74\%) e documentos ligados ao campo das artes gráficas $(13$ processos $-12,03 \%$ ) foram os que mais apareceram nos processos de aquisição.

Para além do dado de que tipologias tradicionais em museus de história foram mais privilegiadas nos processos de aquisição por compra - afinal os objetos relacionados aos campos da Medalhística e da Heráldica figuram entre os itens mais comprados pela instituição -, os dados relativos às compras e doações apresentam muitas semelhanças. 


\section{Tipologia de acervo incorporado por doação (1990-2015)}

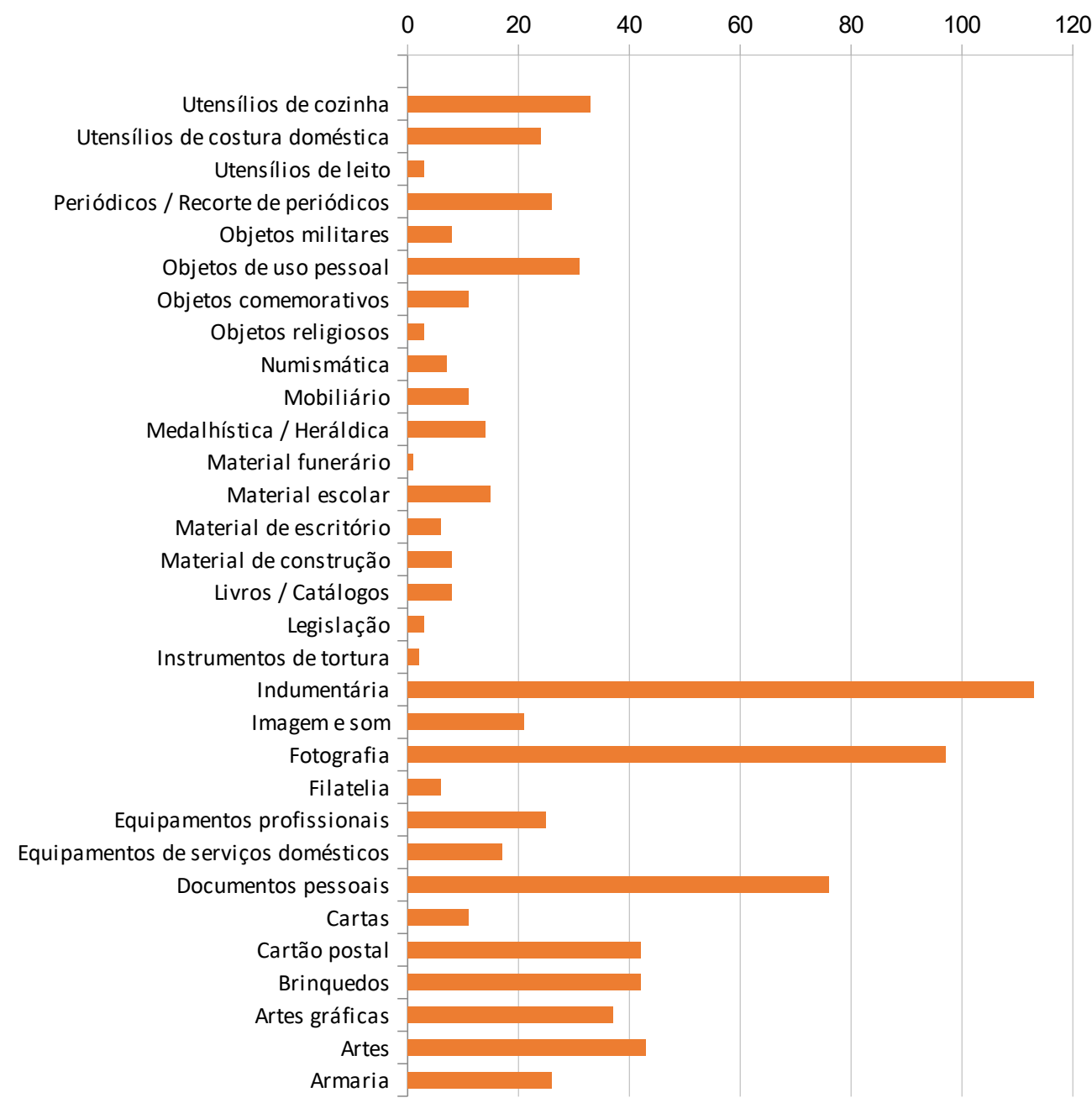

Gráfico 5 - Tipologia de acervo incorporado por doação (1990-2015). Fonte: Vieira, 2018.

Em ambas as modalidades de aquisição de acervo podemos notar uma valorização das fontes de cunho iconográfico - tais como fotografias, cartõespostais, medalhas, condecorações e obras de arte - e das fontes e objetos de uso cotidiano - peças de vestuário, brinquedos, utensílios de guarda, preparo e serviço de alimentos, etc. Tal valorização mostra-se presente também quando se analisa a aquisição de acervo do ponto de vista de sua relação com linhas, projetos e temas de pesquisa desenvolvidos no Museu Paulista. 


\section{Tipologia de acervo incorporado por compra (1990-2015)}

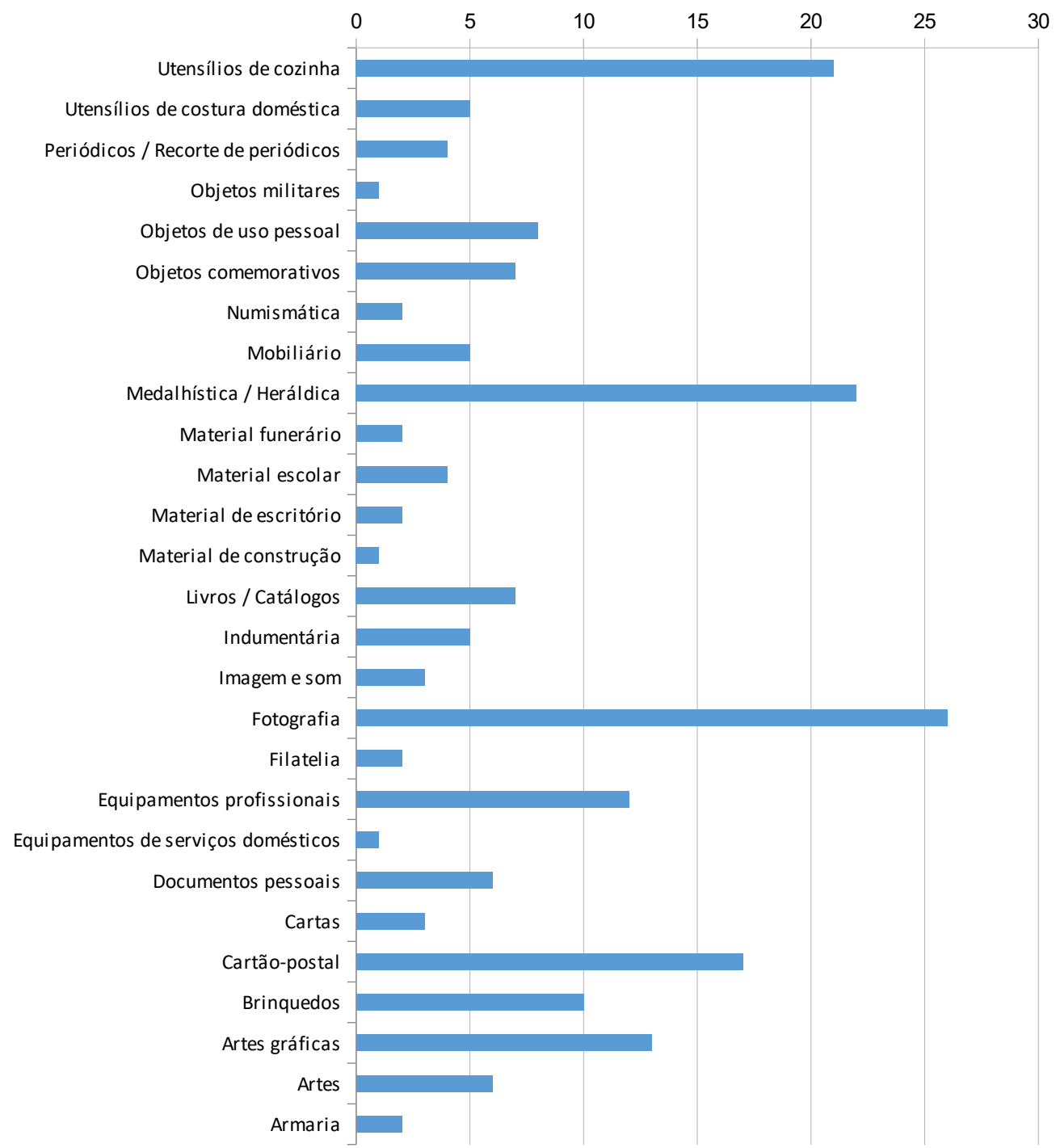

Gráfico 6 - Gráfico acerca da tipologia de acervo incorporado por compra (1990-2015). Fonte: Vieira, 2018

Os gráficos a seguir (gráficos 7 e 8) apresentam, respectivamente, os dados obtidos a partir da análise da justificativa que embasa a aquisição por doação e por compra direta. Tal análise foi empreendida com o objetivo de identificar à quais temáticas os objetos foram relacionados no momento de sua aquisição. 
Linhas e projetos de pesquisa mobilizados como justificativa para a aquisição por compra (1990-2015)

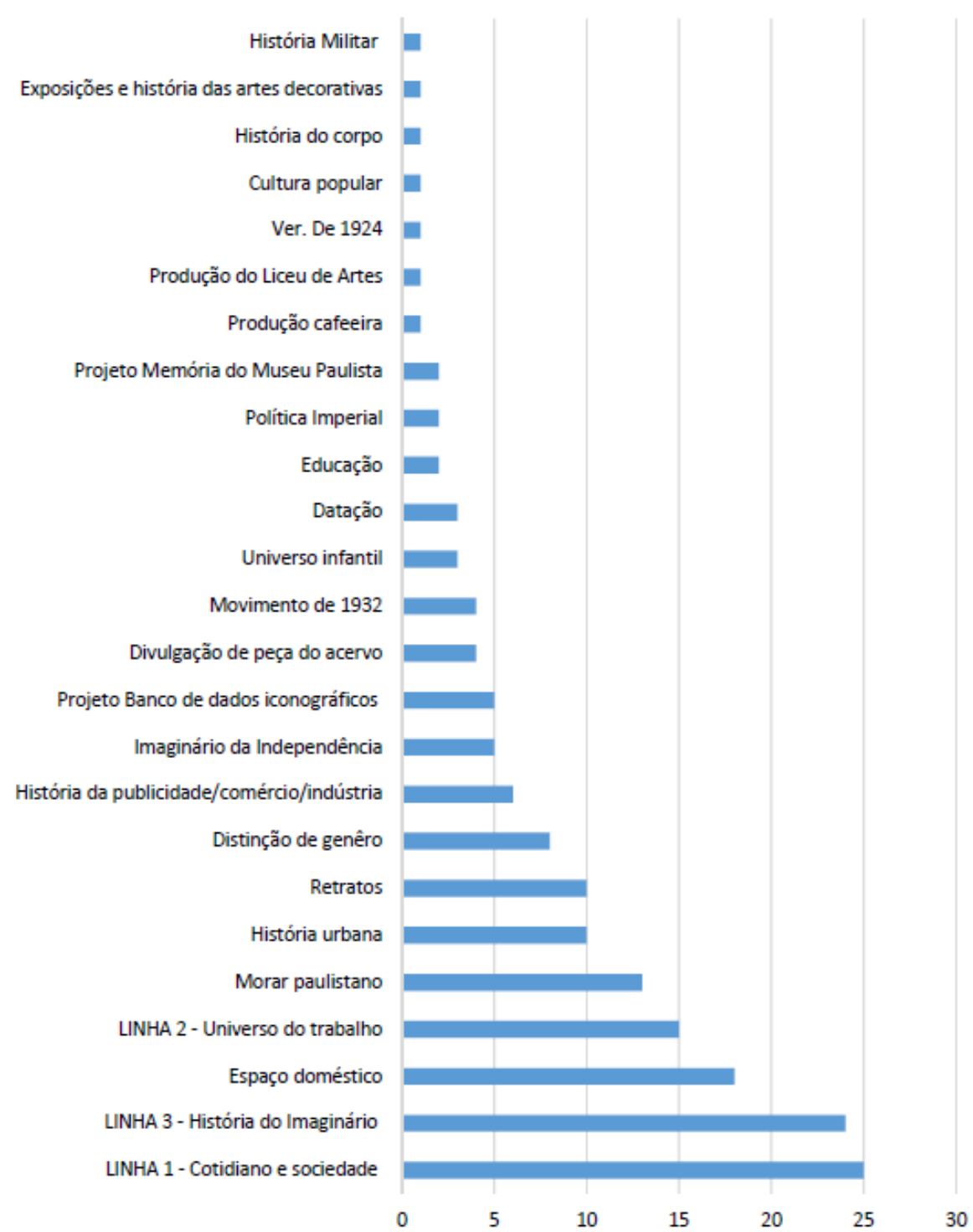

Gráfico 7 - Gráfico acerca linhas e projetos de pesquisa mobilizados como justificativa para a aquisição por compra (1990-2015). Fonte: Vieira, 2018.

A leitura das imagens permite afirmar que as linhas de pesquisa Cotidiano e Sociedade e História do Imaginário foram as mais mobilizadas para justificar o aceite e compra de coleções. Com relação às doações, estas duas linhas foram citadas em dez processos de aquisição cada uma (1 1,76\%); já em relação às compras, as duas foram referenciadas em, respectivamente, $25(29,4 \%)$ e 24 processos $(28,22 \%)$. 
Linhas, projetos e temas de pesquisa mobilizados como justificativa para os aceites das doações (1990-2015)

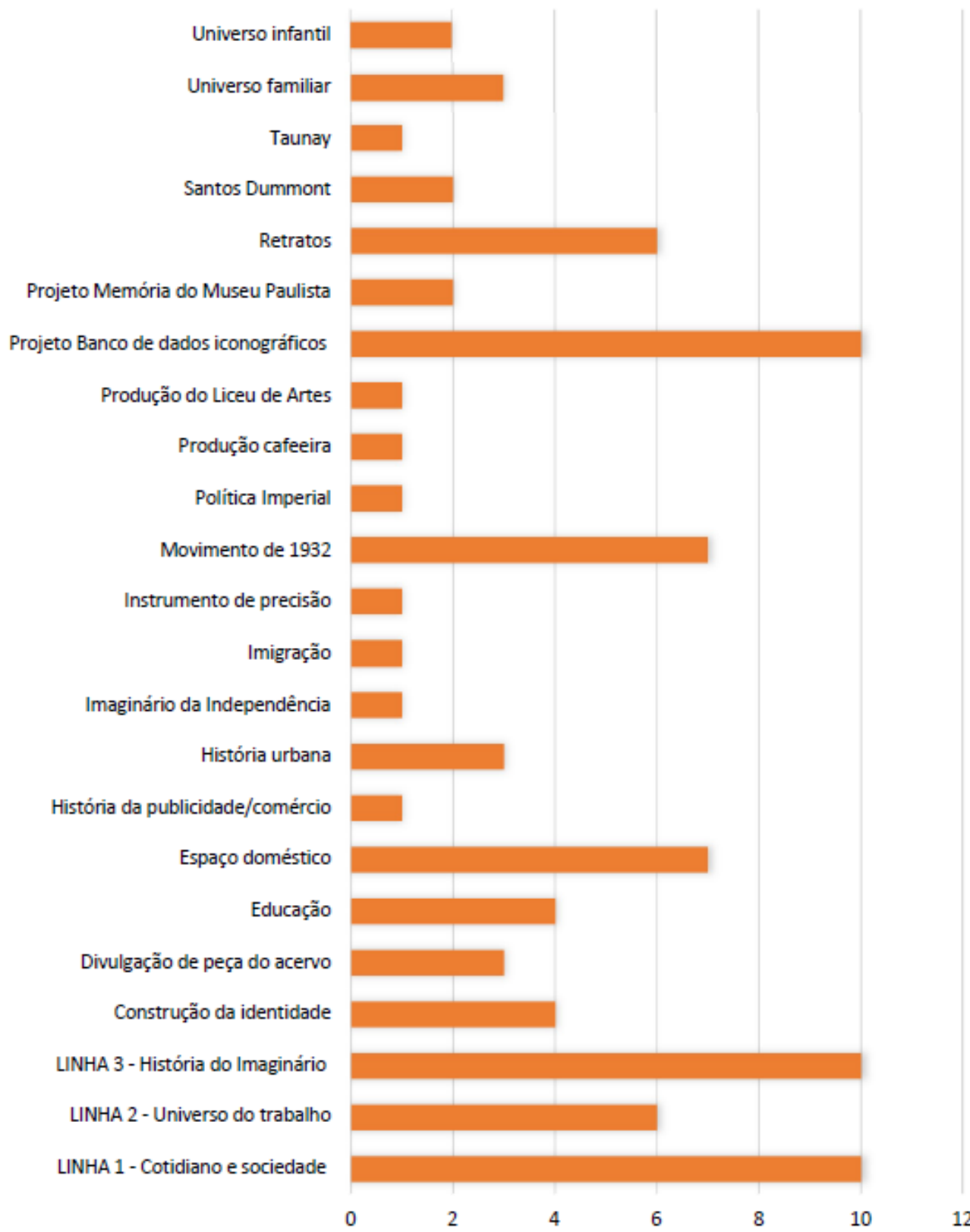

Gráfico 8 - Gráfico acerca das linhas, projetos e temas de pesquisa mobilizados como justificativa para a aquisição por compra (1990-2015). Fonte: Vieira, 2018. 
Com relação aos projetos de pesquisa, o projeto Banco de Dados Iconográficos ${ }^{16}$ foi o que mais fundamentou o recebimento de doações por parte do Museu Paulista, sendo citado em aproximadamente dez processos (1 ,96\%). Em seguida, destacaram-se, em grau decrescente de mobilização, os temas de pesquisa ligados ao Movimento Constitucionalista de 1932 (sete processos 1,37\%), ao espaço doméstico (sete processos - 1,37\%), ao estudo dos retratos (seis processos $-1,17 \%$ ) e ao âmbito educacional (quatro processos - 0,78\%).

Para os processos de aquisição por compra, temos os seguintes dados: os projetos e temas de pesquisa que mais aparecem na documentação enquanto justificativa para aquisição de acervo museológico referem-se ao espaço doméstico (18 processos - 16,66\%), ao projeto de pesquisa $\bigcirc$ Morar Paulistano $^{17}$ (13 processos - 12,03\%), ao estudo de história urbana (dez processos - 9,25\%), de retratística (dez processos - 9,25\%) e de elementos que caracterizam distinções de gênero (oito processos $-7,40 \%$ ).

A referência explicita às linhas, projetos e temas de pesquisa mostrados nos gráficos 6 e 7 e elencados nos parágrafos anteriores atesta o prestígio que os âmbitos do cotidiano e da iconografia possuem na instituição paulista. Essa situação é completamente compreensível quando nos lembramos da conjuntura intelectual, política e social de final do século XX - momento de desenho e implementação do plano diretor do Museu Paulista - e das primeiras décadas do século XXI.

Como já dito anteriormente, o plano diretor institucional de 1990 ecoa muitos pontos-chave de movimentos como a Nova História e a Nova Museologia, principalmente os pontos atrelados ao entendimento ampliado de fonte histórica e de objeto museológico, à ampliação dos temas e objetos de estudo por parte da História e da Museologia e também o entendimento do caráter crítico das narrativas histórica e museológica.

Para além do aspecto discursivo do plano diretor, a análise da documentação permite afirmar que o Museu Paulista desenvolveu uma política de aquisição de acervo fortemente assentada na ampliação dos temas, dos objetos de pesquisa e de grupos sociais representados por seu acervo museológico. No intuito de demonstrar os fundamentos de tal afirmação, será apresentada na próxima seção deste texto uma análise de determinados processos de aquisição de acervo, relacionando-os aos desenvolvimentos científicos das linhas de pesquisa aos quais foram atrelados.
16. De acordo com Makino et al. (2003, p. 266), o projeto Banco de Dados Iconográficos, financiado pelo $\mathrm{CNPq}$, funcionou entre 1992 e 1995 e tinha como objetivo central "a formatação de um banco de dados, que referenciasse coleções dispersas em inúmeras instituições, segundo recortes cronológicos e tipológicos, e que propiciasse o desenvolvimento de problemáticas ligadas às linhas de pesquisa da instituição Iconografia Publicitária (espaço doméstico); Iconografia Fotográfica Urbana (álbuns de família e cartões postais) e Iconografia Impressa (caricatura)".

17. Este projeto será comentado nas próximas páginas. 
No começo da década de 1990, acompanhando tendências advindas do campo da História e da Museologia, o Museu Paulista definiu suas três linhas de pesquisa: Cotidiano e Sociedade, História do Trabalho e História do Imaginário. Ao longo das décadas seguintes, essas temáticas foram sendo desenvolvidas e desdobradas em diversos temas.

A análise dos processos de aquisição de acervo no Museu Paulista, e em especial do item Justificativa para a aquisição, permite afirmar que o museu se manteve alinhado, em boa medida, aos avanços alcançados pela historiografia com relação a tais temas. Para fundamentar tais afirmações, em seguida, serão comentados alguns processos específicos de aquisição de acervo, relacionando-os à linha de pesquisa a qual foi vinculado durante o processo de aquisição.

\section{Linha de pesquisa 1: Cotidiano e Sociedade.}

Os historiadores, em maior ou menor grau, sempre se mantiveram atentos às questões pertinentes ao cotidiano. $\bigcirc$ movimento da Nova História, porém, provocou uma redescoberta desta temática sob o ponto de vista teóricometodológico produzido essencialmente em decorrência da busca por uma história antropológica, também chamada de etno-história:

É na ampliação das áreas de investigação proporcionada pelo esforço teórico e metodológico da Nova História que se situam os estudos sobre o cotidiano, sobretudo pela análise da dimensão política deste, levantando questionamentos sobre as transformações na sociedade, na família e nas condutas de homens e mulheres. ${ }^{18}$

Com relação ao nosso objeto de estudo, gostaria de levantar dois pontos característicos da produção historiográfica acerca do cotidiano. primeiro refere-se à ampliação tipológica das fontes documentais operadas pelos historiadores em razão de seu ofício.

A utilização de fontes diversas - tais como notícias, canções, testamentos, imagens, textos literários e objetos tridimensionais variados - surgiu como consequência necessária para uma geração de historiadores que se propunha a abordar o cotidiano de diferentes grupos das sociedades. José d'Assunção Barros afirma que a história da 
cultura material foi uma das áreas que mais se beneficiou das "preocupações crescentes com a vida cotidiana que surgiram no decurso do século XX". ${ }^{19}$

segundo ponto diz respeito à relação dos estudos do cotidiano e da vida privada com a história das mulheres e as teorias de gênero. Flavia Fernandes de Souza afirma que, no Brasil, as pesquisas sobre o espaço doméstico desenvolveram-se "especialmente nos domínios da História Social do Trabalho", porém, com profundas intersecções com a história das mulheres e a história do cotidiano, por exemplo. ${ }^{20}$

A partir desses breves apontamentos, gostaria de comentar dois processos de aquisição de acervo. $\bigcirc$ primeiro processo constitui um lote de objetos diversos comprados de Elisabete Ferreira Gama em 2012. Esse processo, de número 2012.1.144.33.2, abarca utensílios de guarda, tratamento, preparo, cozimento e serviço de alimentos; aparelhos eletroeletrônicos; brinquedos; artigos de toalete; objetos de uso decorativo e inseticidas (conferir, como exemplo, as figuras 1 a 6). É fundamental realçar a ampla tipologia de objetos presentes neste lote, pois exemplifica a ampliação das fontes documentais referidas logo acima.

Em seguida, cabe atentarmo-nos aos interesses do Museu Paulista em adquirir tais itens. De acordo com o laudo de autenticidade e avaliação constante no referido processo de aquisição, o MP se interessa pelos itens devido aos seguintes motivos: 1) o Museu Paulista desde sua fundação possui objetos de uso doméstico em residências paulistanas; 2) o acervo institucional referente a essa área de estudos tem sido acrescido desde 1990 a partir da implementação do plano diretor do museu; 3) esse lote, especificamente, está relacionado ao desenvolvimento da pesquisa intitulada Morar Paulistano, ligada a um projeto de exposição de longa-duração.

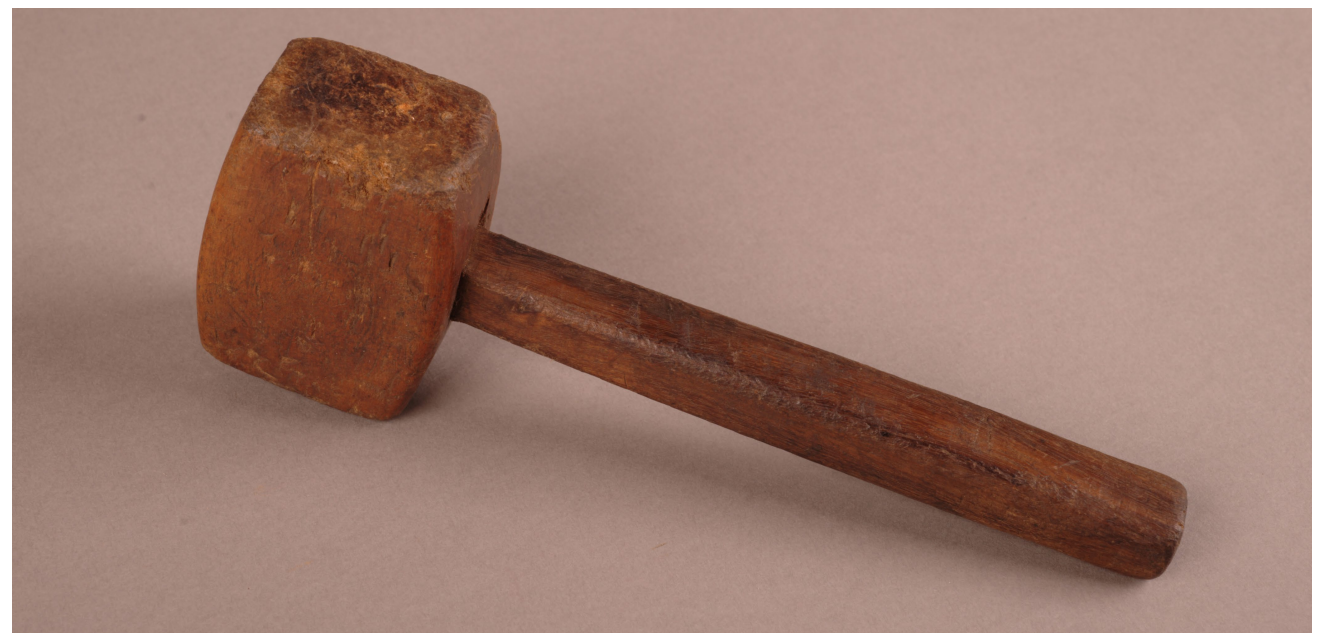

Figura 1 - Martelo de carne de madeira, s/d (Rg: 1 1358). Acervo do Museu Paulista da Universidade de São Paulo. Reprodução: Helio Nobre/José Rosael. 


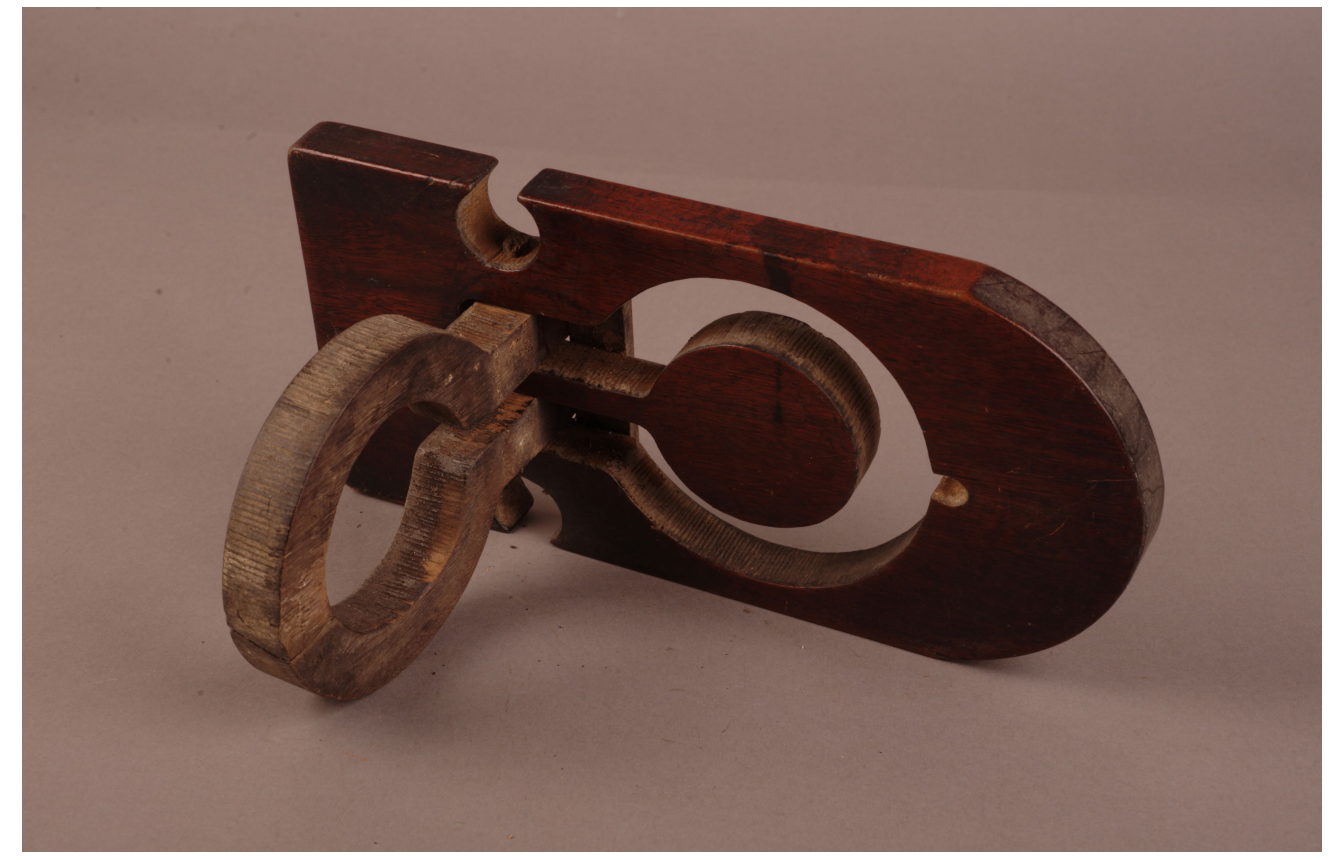

Figura 2 - Suporte para coador de café de madeira, s/d (Rg: 1 1410). Acervo do Museu Paulista da Universidade de São Paulo. Reprodução: Helio Nobre/José Rosael.

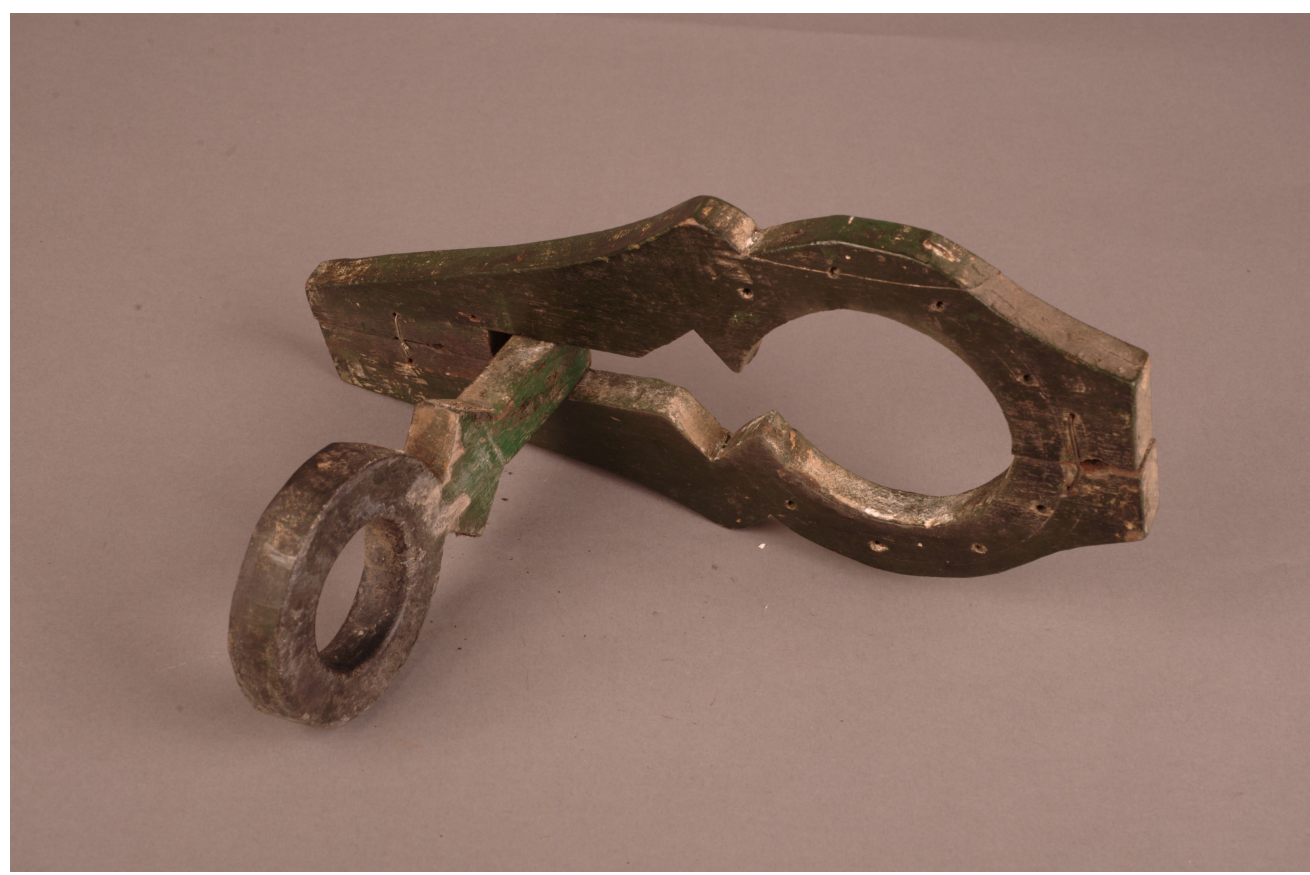

Figura 3 - Suporte para coador de café de madeira, s/d (Rg: 1141 1). Acervo do Museu Paulista da Universidade de São Paulo. Reprodução: Helio Nobre/José Rosael. 


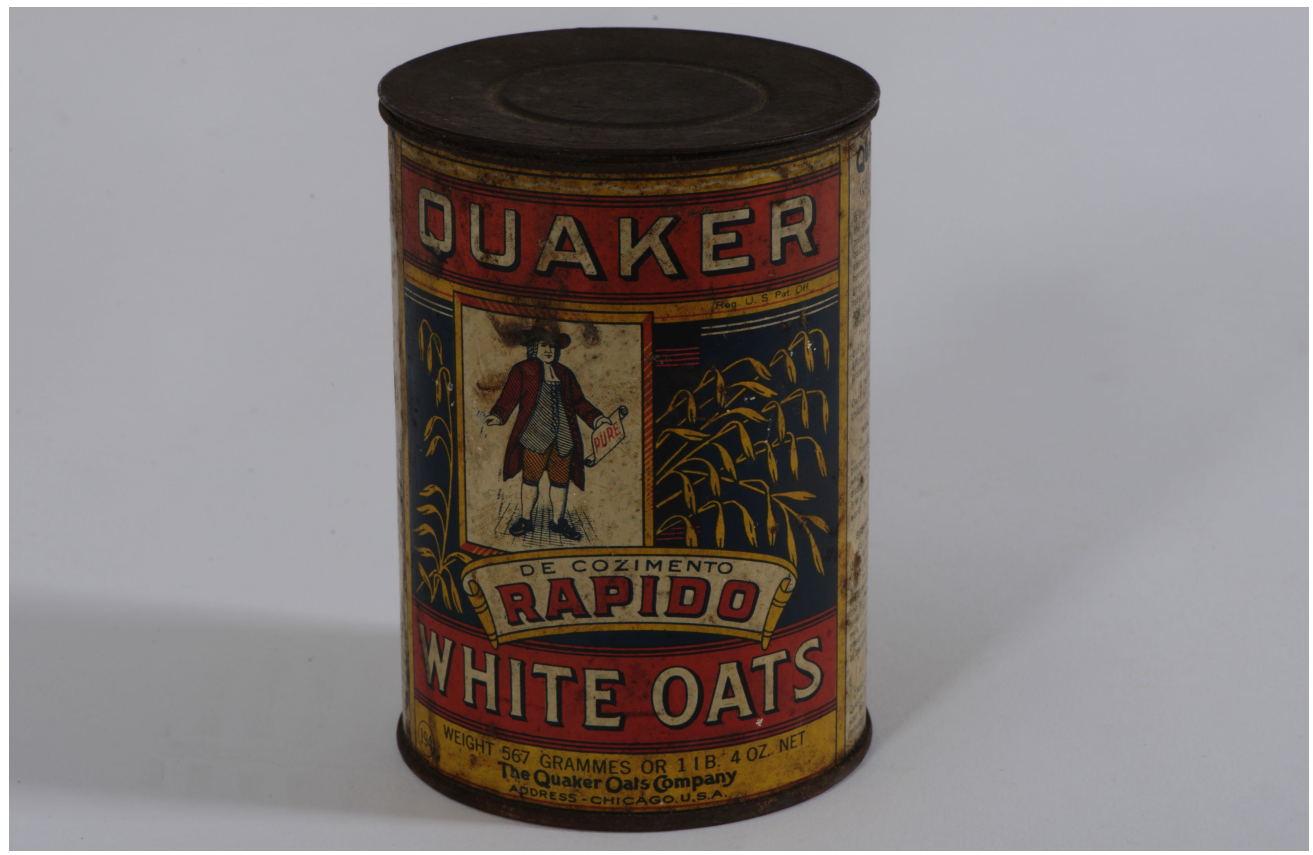

Figura 4 - Lata de aveia de metal, século XX (Rg: 09376). Coleção Ricardo Mendes. Acervo do Museu Paulista da Universidade de São Paulo. Reprodução: Helio Nobre/José Rosael.

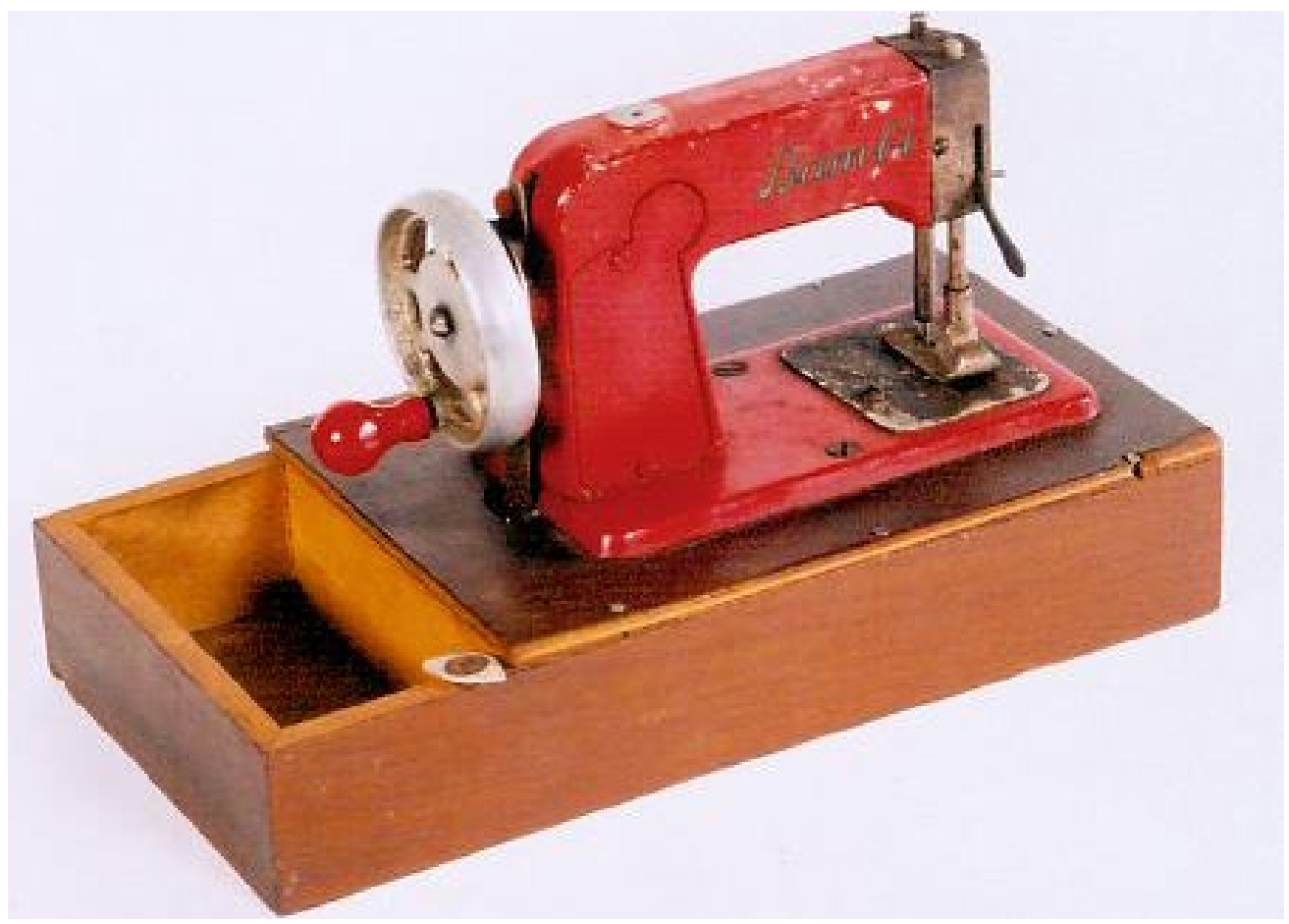

Figura 5 - Máquina de costura de brinquedo de metal e madeira, século XX (Rg: 07975). Acervo do Museu Paulista da Universidade de São Paulo. Reprodução: Helio Nobre/José Rosael. 
21. Processo $\mathrm{n}^{\circ}$ 2012.1.144.33.2/SVDHICO-MP

22. Proces o $\quad \mathrm{n}^{\circ}$ 2012.1.144.33.2/SVDHICO-MP.

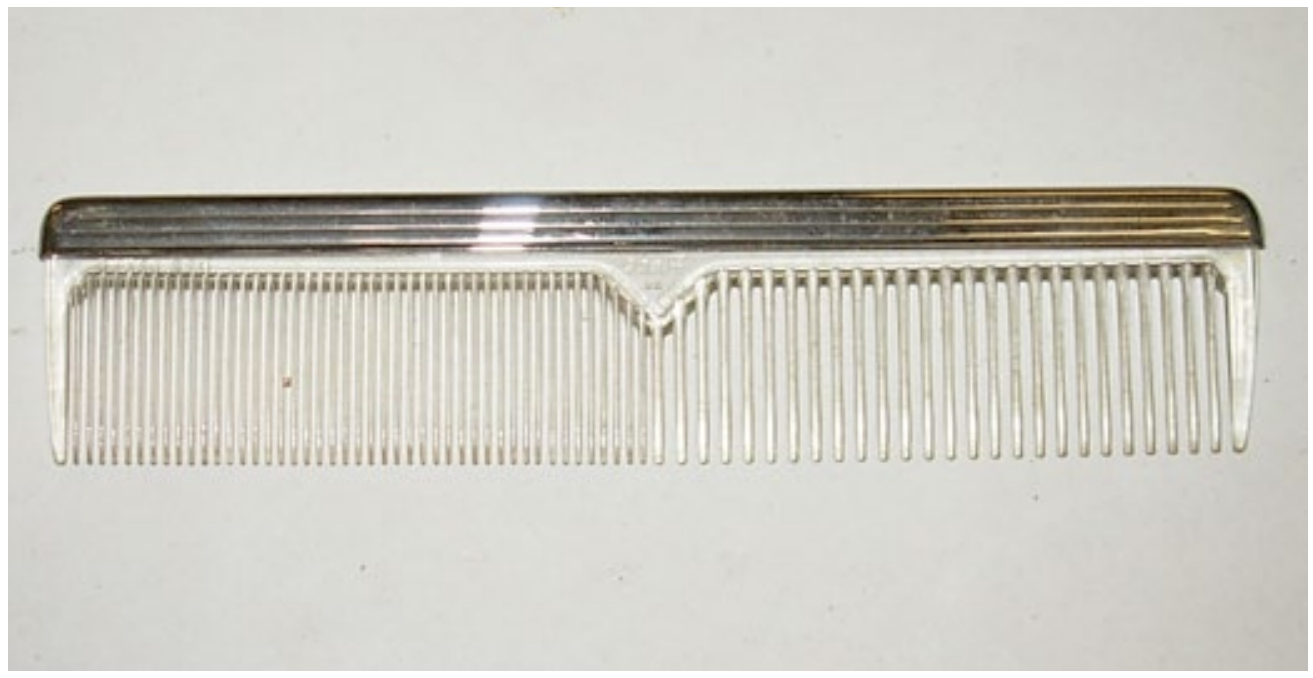

Figura 6 - Pente de plástico transparente, s/d (Rg: 09639). Coleção Inah Meirelles Faria Guimarães. Acervo do Museu Paulista da Universidade de São Paulo. Reprodução: Helio Nobre/José Rosael.

A pesquisa citada acima, de responsabilidade dos professores doutores Vânia Carneiro de Carvalho (curadora), Paulo César Garcez Marins e Solange Ferraz de Lima (curadores assistentes), docentes do Museu Paulista, tem como "questão principal a constituição da 'casa moderna' como um dos polos de difusão de um novo modo de vida associado ao consumismo e às formas de exibição que asseguram prestígio e riqueza social". ${ }^{21}$ Essa pesquisa servirá como referência para a montagem de uma exposição de nome homônimo.

Ainda segundo o laudo de autenticidade e avaliação, o lote adquirido de Elisabete Ferreira Gama integrará os seguintes módulos da exposição: Aprendendo o Feminino, Rituais Domésticos e Trabalho e Consumo. Com relação aos brinquedos presentes no lote, a docente Vânia Carneiro de Carvalho afirma:

Os brinquedos, neste caso peças raras, pois datam dos anos de 1940, reproduzem ambientes do quarto e da cozinha, além de miniaturas de utensílios para preparação de alimentos. Tais objetos serão inseridos na exposição com o objetivo de demonstrar aos visitantes como a menina é treinada para incorporar as tarefas de decorar e trabalhar na casa. ${ }^{22}$

Percebe-se pela leitura do trecho acima o interesse manifestado pela instituição paulista em abordar o cotidiano do trabalho doméstico e sua relação com a história das mulheres e as teorias de gênero. Esse ponto é fundamental para a nossa análise, pois demonstra a estreita relação entre o projeto Morar 
Paulistano - em especial os objetos atrelados ao cotidiano doméstico - e o desenvolvimento de questões relacionadas à distinção de gênero.

Gostaria de problematizar, porém, a pertinência em abordar tais questões com base no binarismo masculino-feminino. Eloisio Moulin de Souza e Alexandre de Pádua afirmam que a aplicação do termo gênero, da forma empregada historicamente nos estudos, mesmo que abarque a compreensão cultural e social da construção das categorias de feminino e masculino, continuam "concebendo e naturalizando a existência de uma visão binária sobre os papéis culturais e sociais. As categorias de análise ainda continuam divididas em dois polos: homem ou mulher" ${ }^{23}$

Devido à complexidade e ao caráter fluido das identidades de gênero na contemporaneidade, considero extremamente importante divulgar outras perspectivas teóricas que procuram se afastar do binarismo de gênero. Vejamos a teoria queer, por exemplo:

O pensamento queer entende que desconstruir a polaridade rígida dos gêneros significa "problematizar tanto a oposição entre eles quanto a unidade interna de cada um" (LOURO, 2008, p. 3 1-32). Para o pensamento queer, o polo masculino também contém o feminino, mesmo que seja de forma postergada e reprimida, e vice-versa. Mas também implica "perceber que cada um desses pólos é internamente fragmentado e dividido (afinal não existe a mulher, mas várias e diferentes mulheres que não são idênticas entre si, que podem ou não ser solidárias, cúmplices ou opositoras)". ${ }^{24}$

Destaco neste texto que uma das consequências essenciais da desconstrução da oposição binária reside na possibilidade de abordagem de diferentes masculinidades e feminilidades:

A concepção dos gêneros como se produzindo dentro de uma lógica dicotômica implica um pólo que se contrapõe a outro (portanto uma idéia singular de masculinidade e de feminilidade), e isso supõe ignorar ou negar todos os sujeitos sociais que não se "enquadram" em uma dessas formas. Romper a dicotomia poderá abalar o enraizado caráter heterossexual que estaria na visão de muitos/as, presente no conceito "gênero". ${ }^{25}$

Tal debate se mostra mais urgente quando lembramos as constatações dos pesquisadores Jean Baptista e Tony Boita com relação à ausência de feminilidades e masculinidades não hegemônicas no debate pautado pelas instituições museológicas. Tal situação repete-se com relação ao Museu Paulista, pois na documentação consultada não foram encontradas referências à abordagem de questões concernentes a essa temática no Estado de São Paulo, fato que pode ser
23. Souza; Carrieri (2010, p. 58).

24. Louro (2008, p. 34) apud ibid., p. 64.

25. Ibid., p. 64. 
26. Baptista; Boita (2017, p. 110).

27. Ibid., p. 111. compreendido a partir das origens patriarcais do conceito de patrimônio, "o que explica a heteronormatividade na seleção do que deve ser tombado ou registrado". ${ }^{26}$

Sendo assim, já que o Museu Paulista tem se empenhado nas últimas décadas em ampliar a representatividade social de seus acervos, é imperioso que a instituição inclua em seus interesses prioritários a discussão acerca de identidades de gênero e sexualidades que fujam do padrão heteronormativo. Afinal, além de constituir "uma ação cidadã interessada em colaborar na superação de fobias à diversidade sexual impregnadas na cultura nacional", ${ }^{27}$ a articulação entre a memória LGBT e as referências de gêneros não hegemônicas com o patrimônio presente em nossas instituições museológicas contribuirá para uma compreensão mais alargada e profunda das relações sociais.

Seguindo em frente, voltemos nossas atenções para a aquisição de um lote de 46 itens doados pelas irmãs Aracy Amaral, Suzana Amaral e Ana Maria Amaral em 1999. Esse lote contém 37 peças de indumentária pertencentes à mãe das doadoras, Nadya Abreu Amaral, uma peça de indumentária pertencente a Antonio de Abreu Amaral, o primeiro filho de Nadya Abreu Amaral, um aparelho de barbear de Aguinaldo Amaral e um conjunto de apliques para roupa pertencentes a Aracy Amaral (as figuras 7 a 11 são de peças adquiridas nesse lote).

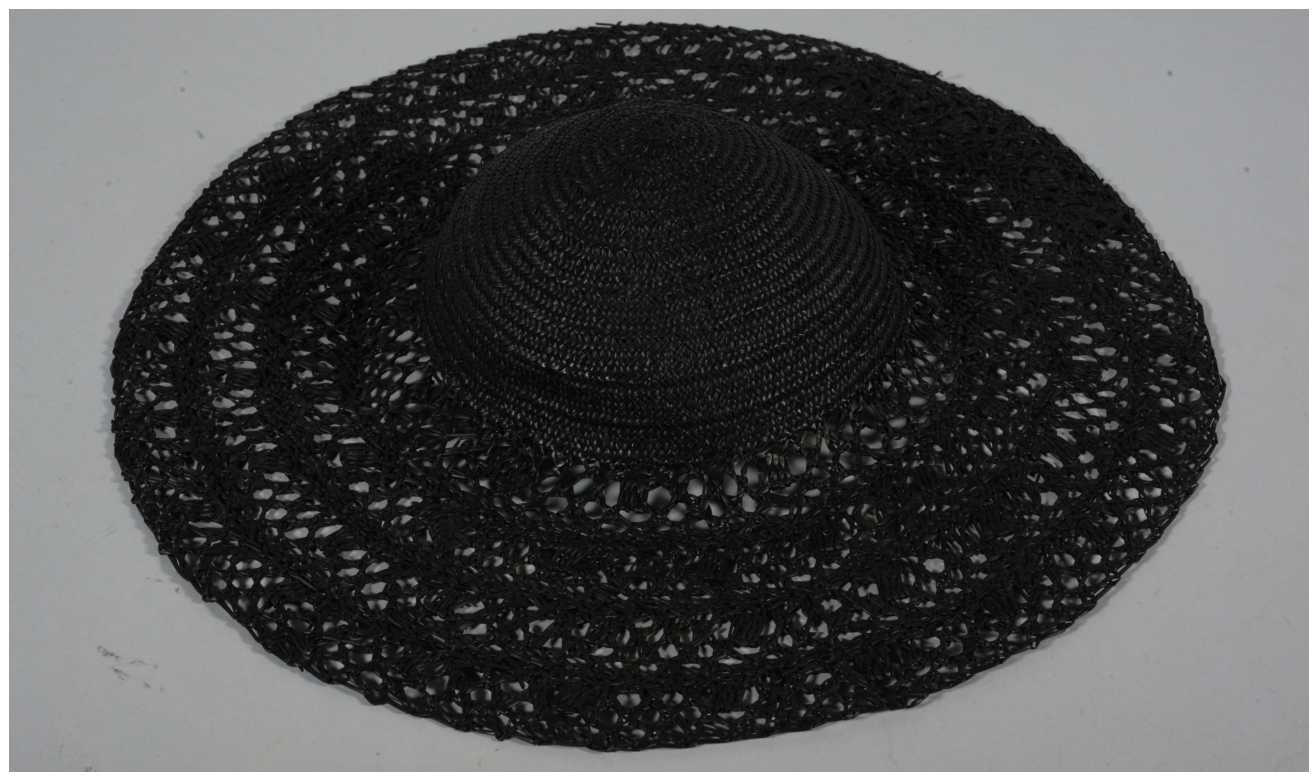

Figura 7 - Chapéu feminino de fibra de ráfia italiana, 1947-1948 (Rg: 08700). Coleção Nadya Abreu Amaral. Acervo do Museu Paulista da Universidade de São Paulo. Reprodução: Helio Nobre/José Rosael. 


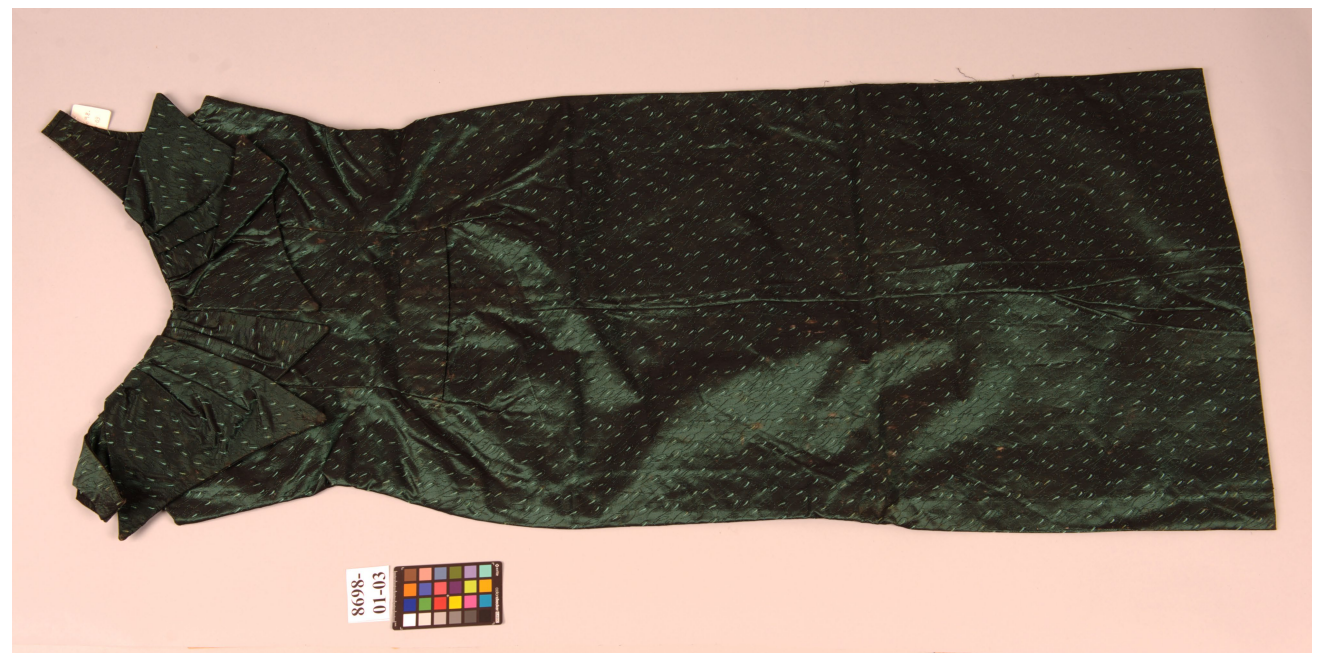

Figura 8 - Vestido longo de alça em tafetá de seda pura, 1960 (Rg: 08698). Coleção Nadya Abreu Amaral. Acervo do Museu Paulista da Universidade de São Paulo. Reprodução: Helio Nobre/José Rosael.

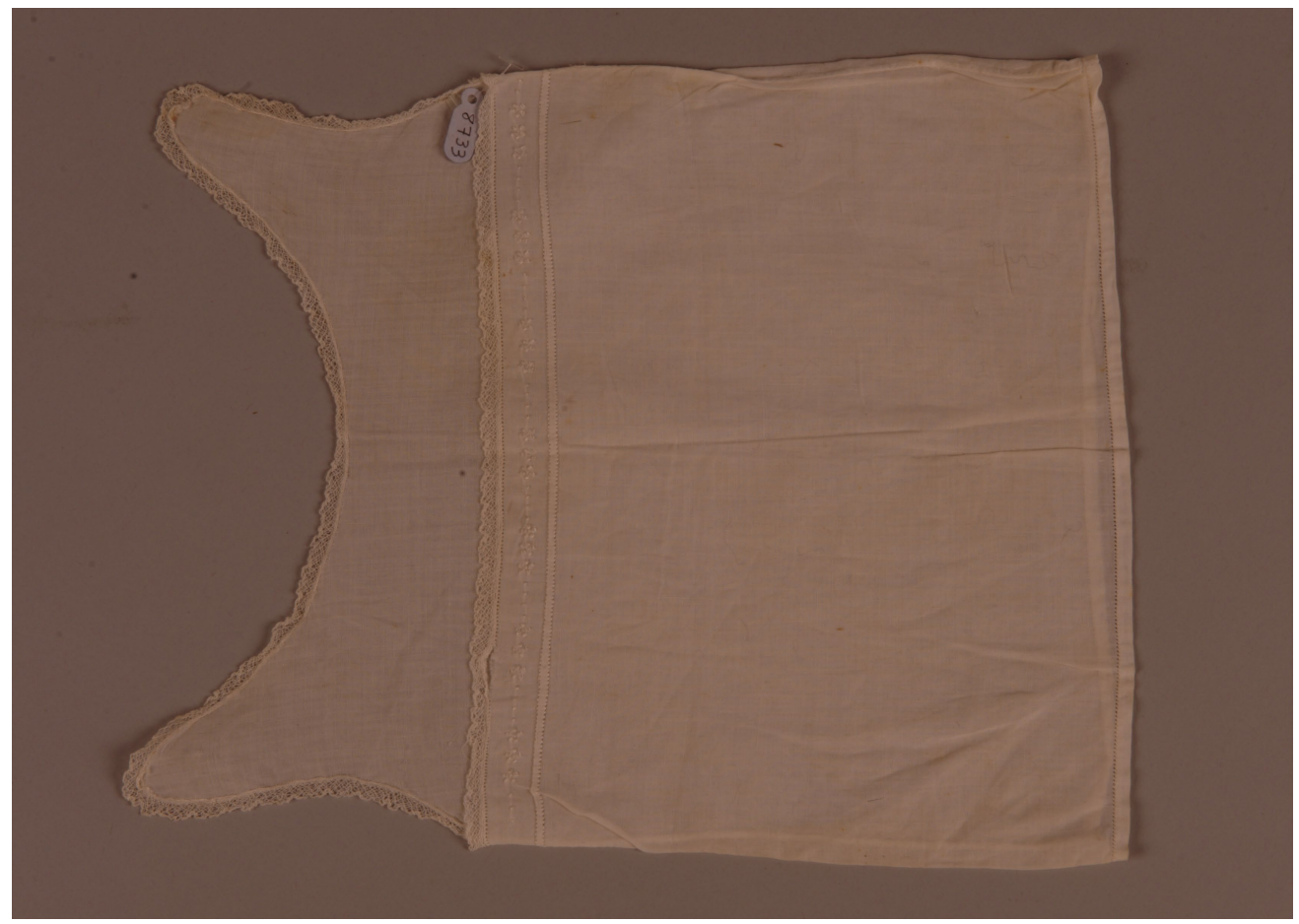

Figura 9 - Camisa de pagão de cambraia de linho branco, 1930 (Rg: 08733). Coleção Nadya Abreu Amaral. Acervo do Museu Paulista da Universidade de São Paulo. Reprodução: Helio Nobre/José Rosael. 
Figura 10 - Camisola de dormir em palha de seda, s/d (Rg: 08696). Coleção Nadya Abreu Amaral. Acervo do Museu Paulista da Universidade de São Paulo. Reprodução: Helio Nobre/José Rosael.

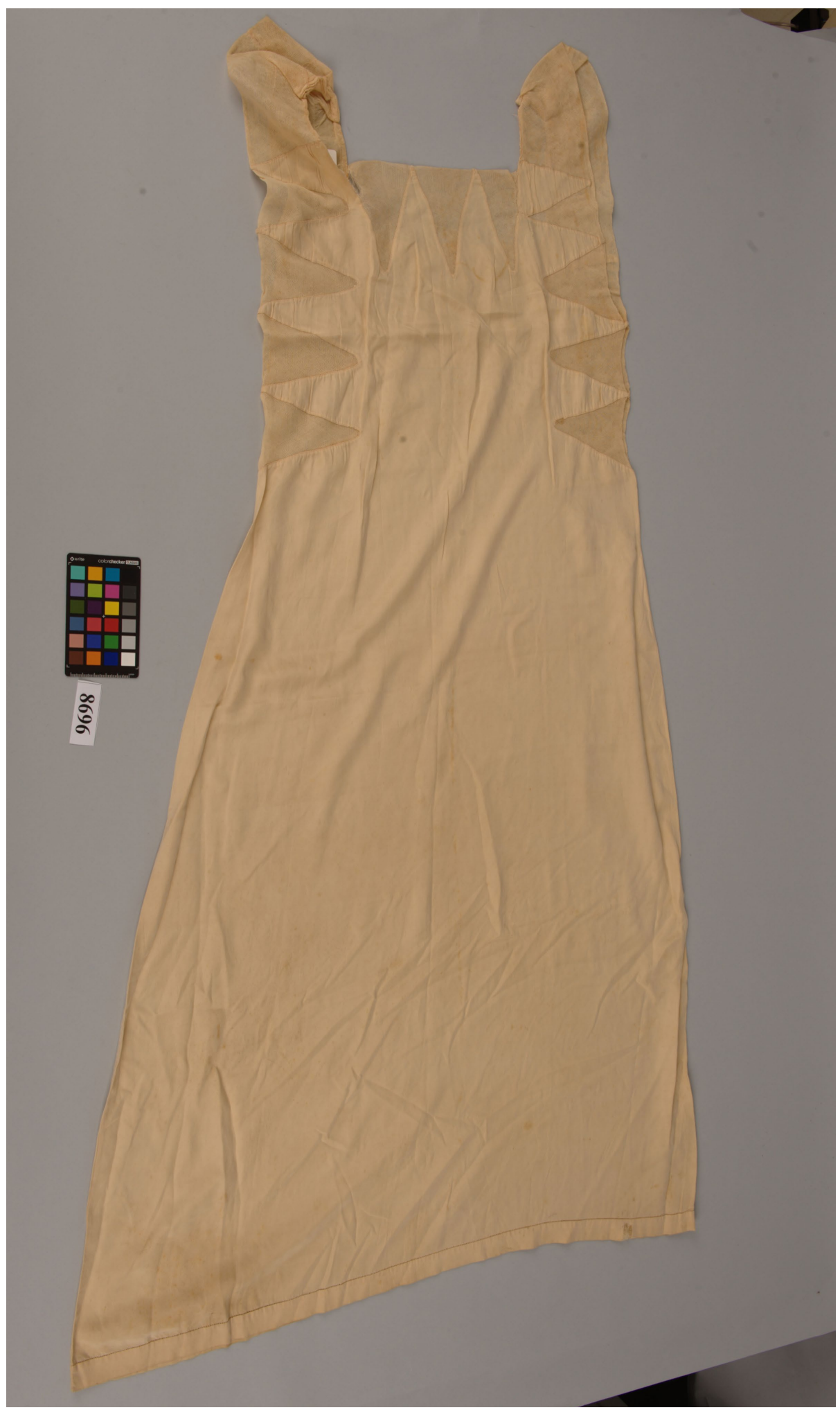




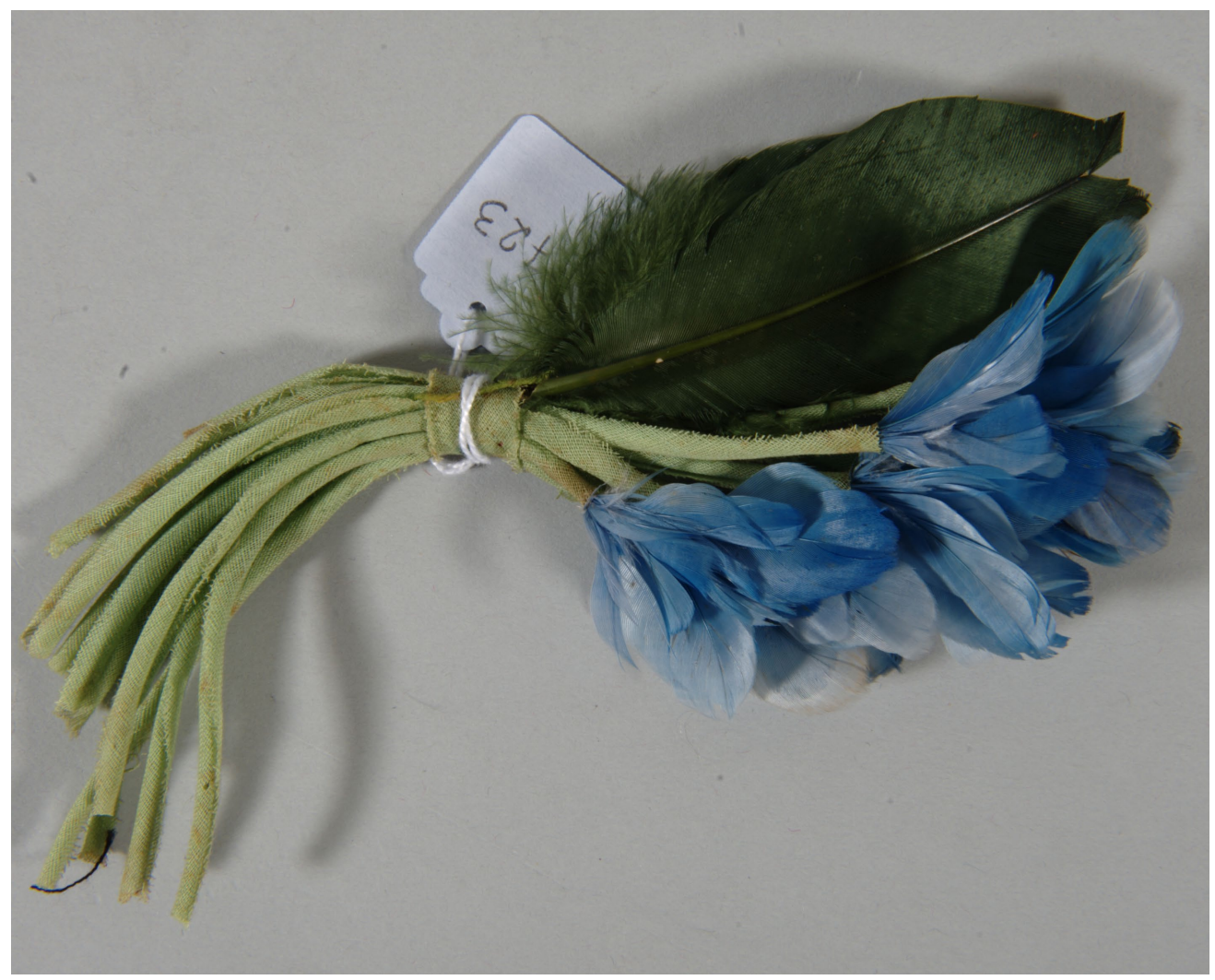

28. Paula (2006, p. 266).

29. Deve-se salientar que este documento está datado em 9 de agosto de 2004, ou seja, cinco anos após o recebimento da carta de doação das irmãs Amaral. Tal dado exprime um enorme descompasso entre o recebimento de manifestações de doações e a análise institucional com relação a tais atividades.

Figura 11 - Aplique para indumentária feminina imitando flores, 1950 (Rg: 08723). Coleção Nadya Abreu Amaral. Acervo do Museu Paulista da Universidade de São Paulo. Reprodução: Helio Nobre/José Rosael.

Este conjunto foi escolhido por permitir abordar diversas questões relativas à prática de aquisição de objetos de indumentária, dentre as quais destaco inicialmente as seguintes: em primeiro lugar, a historiadora e conservadora de têxtil do Museu Paulista, Teresa Cristina Toledo de Paula, afirma que após as mudanças institucionais ocorridas no Museu Paulista no final da década de 1980, as coleç̃es com objetos têxteis cresceram substancialmente, chegando a ser estimado um acréscimo superior a $170 \% ;{ }^{28}$ segundo, os objetos relacionados à indumentária - em especial à indumentária feminina - consistem em uma das tipologias de acervo mais recebidas pela instituição no período compreendido nesta pesquisa.

Antes de pautar outros pontos característicos da aquisição de artigos de indumentária, proponho que enfoquemos a justificativa ${ }^{29}$ para o aceite da doação realizada pela família Amaral. Assinada pelo supervisor do Serviço de Objetos, Adilson José de Almeida, o documento afirma: 
30. Processo de doação de Aracy Amaral, Suzana Amaral e Ana Maria Amaral 1999/ SVDHICO-MP, grifo do autor.

31. Paula (op. cit., p. 293)
A prof Aracy Amaral oferece ao Museu Paulista, juntamente com suas irmãs, uma doação de quarenta (46) itens distribuídos da maneira como segue.

Trinta e sete (37) peças de indumentária feminina que pertenceram à mãe das doadoras, Nadya Abreu Amaral, importadas (Argentina, Itália, Espanha, França) e utilizadas em sua grande maioria nas décadas de 1940-1950, mas com alguns exemplares das duas décadas anteriores. De destaque neste conjunto uma camisola do primeiro dia de núpcias e um casaco parisiense Agneu Rase.

Uma (1) camisa de pagão da década de 1930 de Antonio de Abreu Amaral, pintor, primeiro filho de Nadya Amaral. Um (1) aparelho de barbear, com estojo, para utilização em viagens, marca BRIX, da década de 1940, que pertenceu a Aguinaldo Amaral, esposo de Nadya Amaral. Sete (7) apliques para roupa do vestuário de festa de 15 anos da profa Aracy Amaral. ${ }^{30}$

Primeiramente, mostra-se interessante notarmos no trecho acima os destaques escolhidos pelo autor com relação ao conjunto dos itens: trata-se de peças importadas, relativas majoritariamente às décadas de 1930 e 1940; há ainda o destaque ao material de uma peça específica - agneu rase, ou seja, pele de cordeiro -, e à peça utilizada em data especial - camisola usada no primeiro dia de núpcias. Esses apontamentos realizados pelo autor nos direcionam para o que ele e consequentemente o Museu Paulista, representado a partir de sua atuação, consideram interessantes no tocante ao acervo de indumentária.

Em segundo lugar, considero essencial ecoar as críticas feitas por Teresa Cristina Toledo de Paula sobre a prática de aquisição de acervo têxtil no Museu Paulista:

O exagero do colecionismo refletiu-se sobre os tecidos e assemelhados através da falta de critérios de aquisição e formação das coleções, antes e ainda agora. Tudo interessava, fossem um, cinco ou cinquenta tecidos incas ou uniformes militares: a idéia de coleção, nesses museus [Museu Paulista e Museu de Arqueologia e Etnologia da USP] confundiu-se com quantidade, com várias e muitas unidades, pouco importando, por exemplo, qualquer um dos critérios praticados no estrangeiro. Acumulou-se. E acumulou-se mal. $\bigcirc$ colecionismo exagerado materializou a falta de sentido, expandindo o tamanho daquilo que não se preservou. ${ }^{31}$

A análise de Toledo de Paula se mostra pertinente quando retomamos o dado de que os objetos têxteis foram incorporados de forma esmagadora a partir das doações e também quando notamos a superficialidade característica da justificativa assinada por Adilson José de Almeida. Neste documento, em vez de nos depararmos com uma listagem dos motivos de interesse de tais 
peças para ao Museu Paulista, encontramos uma segunda descrição dos itens com ênfase em seus materiais e usos excepcionais.

Por fim, cabe ressaltar que, conforme Toledo e Paula e os dados levantados por esta pesquisa, os objetos e acessórios de indumentária encontrados no Museu Paulista são predominantemente femininos. ${ }^{32}$ Tal fato reforça estereótipos acerca da relação entre o campo de estudos dos usos do vestuário e o gênero feminino e impede que a instituição e pesquisadores interessados abordem distinções de gênero do ponto de vista da indumentária, visto que a coleção institucional não se encontra minimamente equalizada na perspectiva da constituição de gênero dos indivíduos.

\section{Linha de pesquisa 2: Universo do Trabalho}

Assim como o tópico cotidiano e sociedade, o universo do trabalho sempre suscitou o interesse por parte dos historiadores e de diversos outros profissionais do campo das ciências humanas. No Brasil, segundo Lilian de Souza Lima Matias, os primeiros estudos sobre o tema surgiram por volta da década de 1950, os quais apresentavam um forte enfoque nos movimentos e organizações operárias da Primeira República. ${ }^{33}$

Ao longo das décadas de 1960 e 1970, a historiografia brasileira ficou marcada pela ampliação do recorte temporal dos estudos, bem como pela forte ênfase à ideia de subordinação dos trabalhadores aos patrões. Como pano de fundo dessa produção, encontravam-se questões de ordem desenvolvimentista e econômica do país e a busca pela identificação do processo de surgimento da consciência da classe operária.

Foi durante a década de 1980 que mudanças conceituais e metodológicas alteraram a produção historiográfica sobre o universo do trabalho. Sidney Chalhoub e Fernando Teixeira da Silva afirmam que uma das características essenciais da produção acerca da "história dos trabalhadores decorrente da virada analítica da década de 1980 pode ser resumida na ideia de alargamento de horizontes conceituais e possibilidades de pesquisa". ${ }^{34}$ Ampliaram-se tanto o conceito de trabalhador, não mais centrado na ideia de classe, como os recortes temporais, geográficos e temáticos.

Outro ponto fundamental da produção pós-1980 diz respeito ao interesse dos historiadores por tópicos que extrapolavam o ambiente de trabalho. Fruto do distanciamento das "grandes interpretações", também característico das décadas finais do século XX, os autores voltaram-se para questões relativas a "aspectos como cultura, etnicidade, gênero, educação, habitação etc." , a partir da perspectiva do 
35. Ibid., p. 40.

36. Para mais informações sobre a fábrica e vila operária, localizadas na cidade de São Paulo, cf., por exemplo, os trabalhos de Morangueira (2006) e Jucá; Lopes (2008).

37. Processo de doação de Suely Moraes Ceravolo, de 1993/SVDHICO-MP
Figura 12 - Álbum "Lembrança do Cotonifício 'Scarpa' e da sua organização social na Villa Scarpa", 1926 (Rg: 12372). Acervo do Museu Paulista da Universidade de São Paulo. Reprodução: Helio Nobre/José Rosael. cotidiano dos trabalhadores. ${ }^{35}$ Surgiram, portanto, estudos que tratavam do dia a dia das fábricas e das práticas de lazer, entre outros assuntos.

Sendo assim, vale destacar o processo de doação, empreendido pela museóloga Suely Moraes Ceravolo, do álbum intitulado "Lembrança do Cotonifício 'Scarpa' e da sua organização social na Villa Scarpa", que pertencera à avó da doadora, Maria de Almeida Moraes, ex-funcionária da Fábrica Maria Zélia da Companhia Nacional de Tecidos de Juta - posteriormente denominada Cotonifício Scarpa. ${ }^{36}$ Para além da relação trabalhista, está expressa na carta de doação que Maria de Almeida Moraes foi moradora da Vila Maria Zélia na companhia de seu esposo, José Moraes. As figuras 12, 13 e 14 são imagens de parte do álbum.

De acordo com o laudo técnico, assinado pela docente Solange Ferraz de Lima, o álbum doado por Ceravolo interessa ao Museu Paulista pelas seguintes razões:

O Museu Paulista vem se empenhando na formação de coleções iconográficas que atendam às linhas de pesquisa definidas em 1989. Uma delas, a História do Imaginário, abrange os estudos de representações constituídas a partir de referências materiais, sejam estas imagens visuais, objetos ou mesmo ambientes urbanos.

É de interesse para a instituição por informar sobre a organização material de uma importante indústria paulista e sobre vilas operárias, integrando também a linha de pesquisa referente ao Universo do Trabalho. ${ }^{37}$

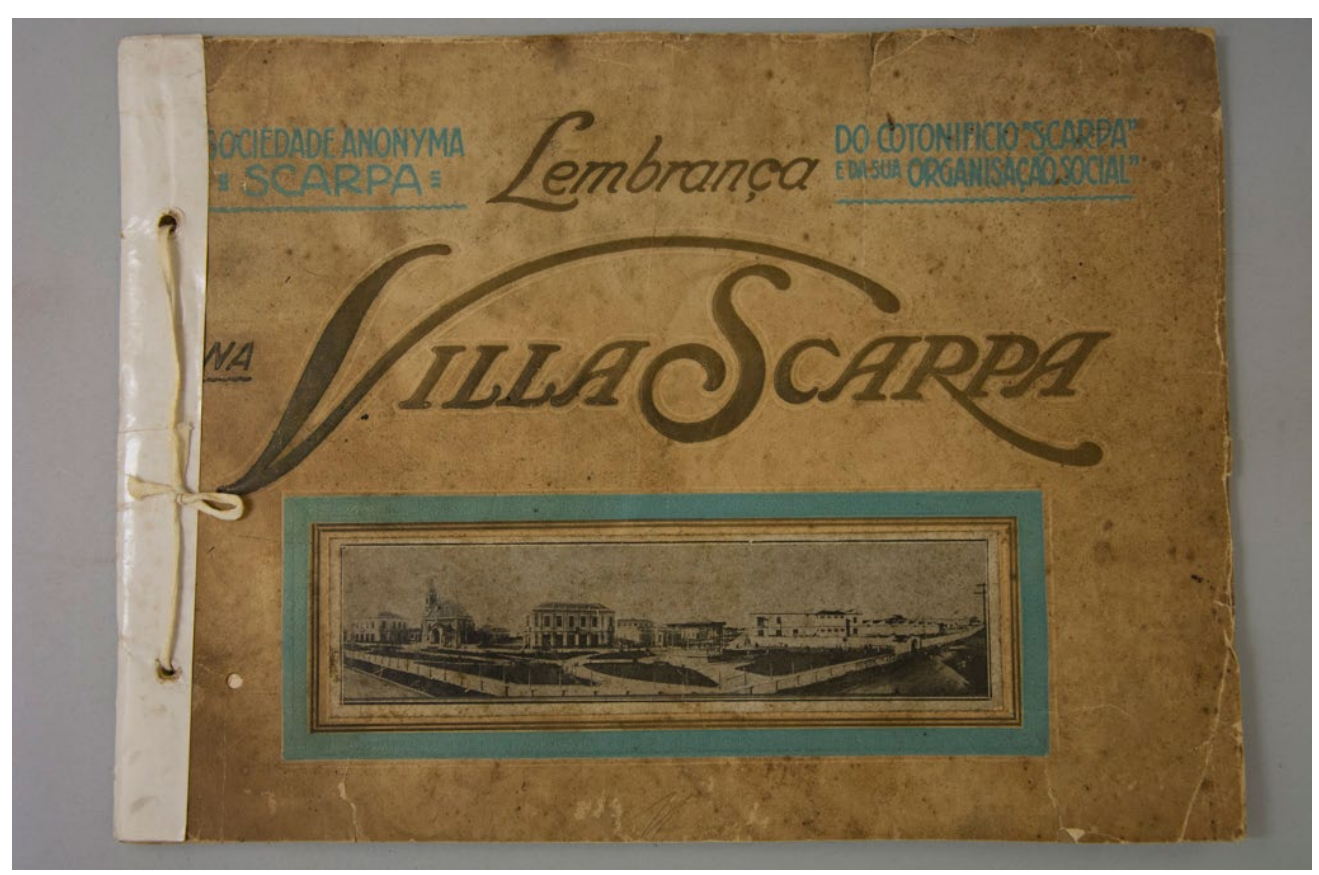




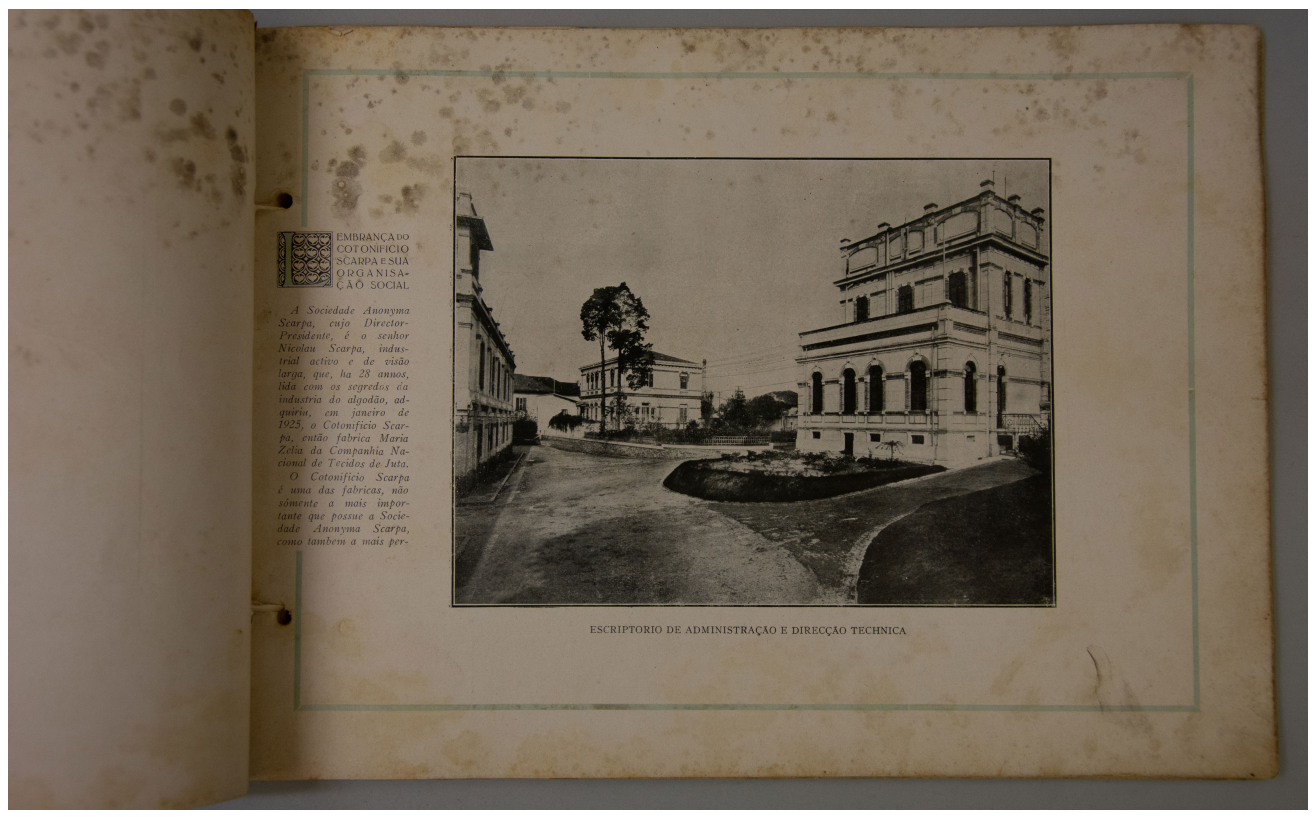

Figura 13 - Álbum "Lembrança do Cotonifício 'Scarpa' e da sua organização social na Villa Scarpa", 1926 (Rg: 12372). Acervo do Museu Paulista da Universidade de São Paulo. Reprodução: Helio Nobre/José Rosael.

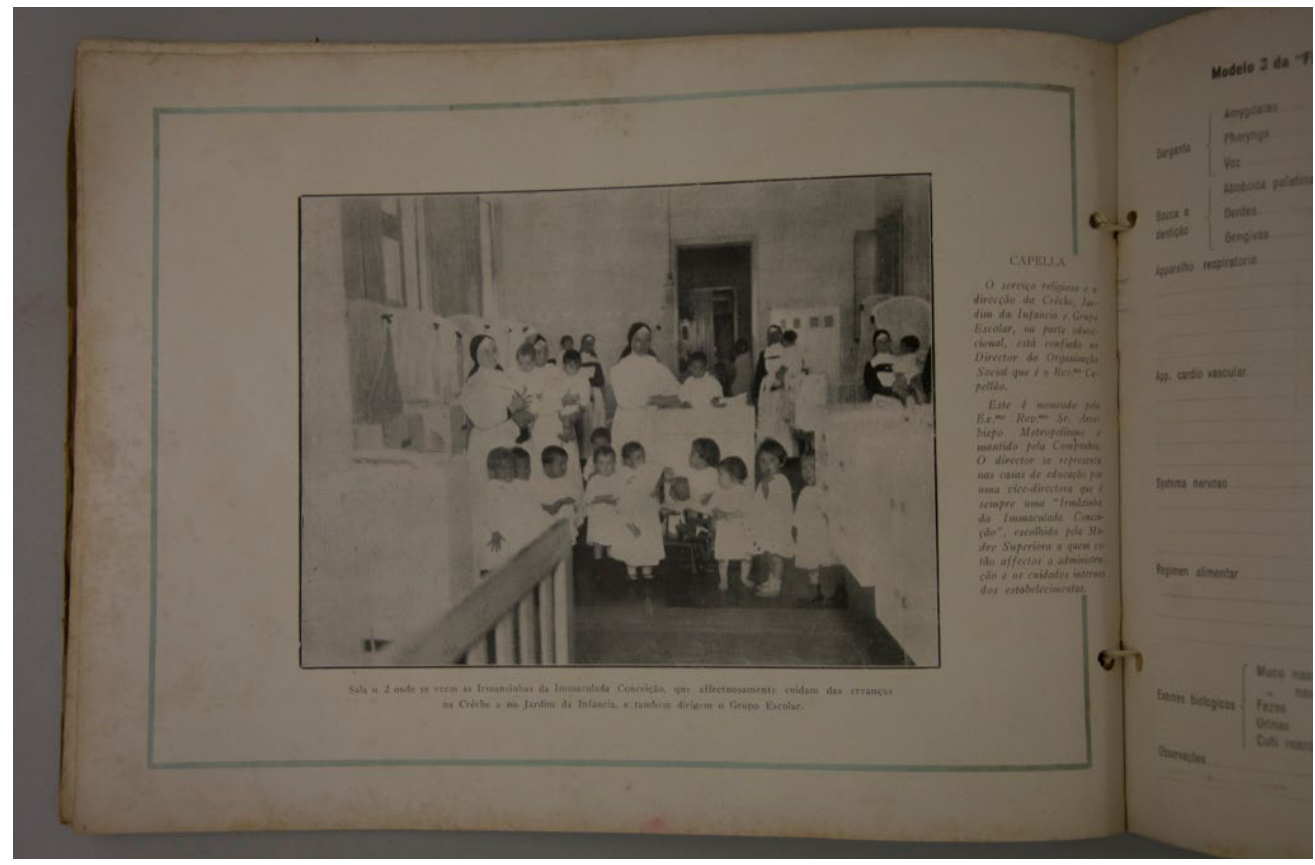

Figura 14 - Álbum "Lembrança do Cotonifício 'Scarpa' e da sua organização social na Villa Scarpa", 1926 (Rg: 12372). Acervo do Museu Paulista da Universidade de São Paulo. Reprodução: Helio Nobre/José Rosael. 
Figura 15 - Capacete usado por trabalhadores ferroviários, [s. d.] (Rg: 09950). Coleção Ferroviária. Acervo do Museu Paulista da Universidade de São Paulo. Reprodução: Helio Nobre/José Rosael.

Figura 16 - Seis peças para roldana de cabine de comando ferroviária, [s. d.] (Rg: 09945). Coleção Ferroviária. Acervo do Museu Paulista da Universidade de São Paulo. Reprodução: Helio Nobre/José Rosael.
O interesse do Museu Paulista por referências à construção e organização de vilas operárias, edificações características do final do século XIX e primeiro quartel do século XX mostra o alinhamento da instituição com a produção historiográfica, de acordo com as características citadas acima.

O segundo processo de aquisição de acervo que abordarei, de número 2002. 1. 120.33.6, também se encontra na esteira dessa tipologia de estudos, principalmente por seu vínculo com o cotidiano de trabalhadores ferroviários. O conjunto em questão, adquirido de Mauricio da Silva Medeiros, abrange um lote de mobiliário e demais itens de vagões ferroviários, tais como cadeiras de restaurantes, encostos, objetos de serviço culinário, etc., e também de itens de uso cotidiano por trabalhadores de ferrovias, como, por exemplo, capacetes, peças de engate de vagões, alavancas, ferramentas, marcadores, entre outros (conferir parte deste lote nas figuras 15 a 18).
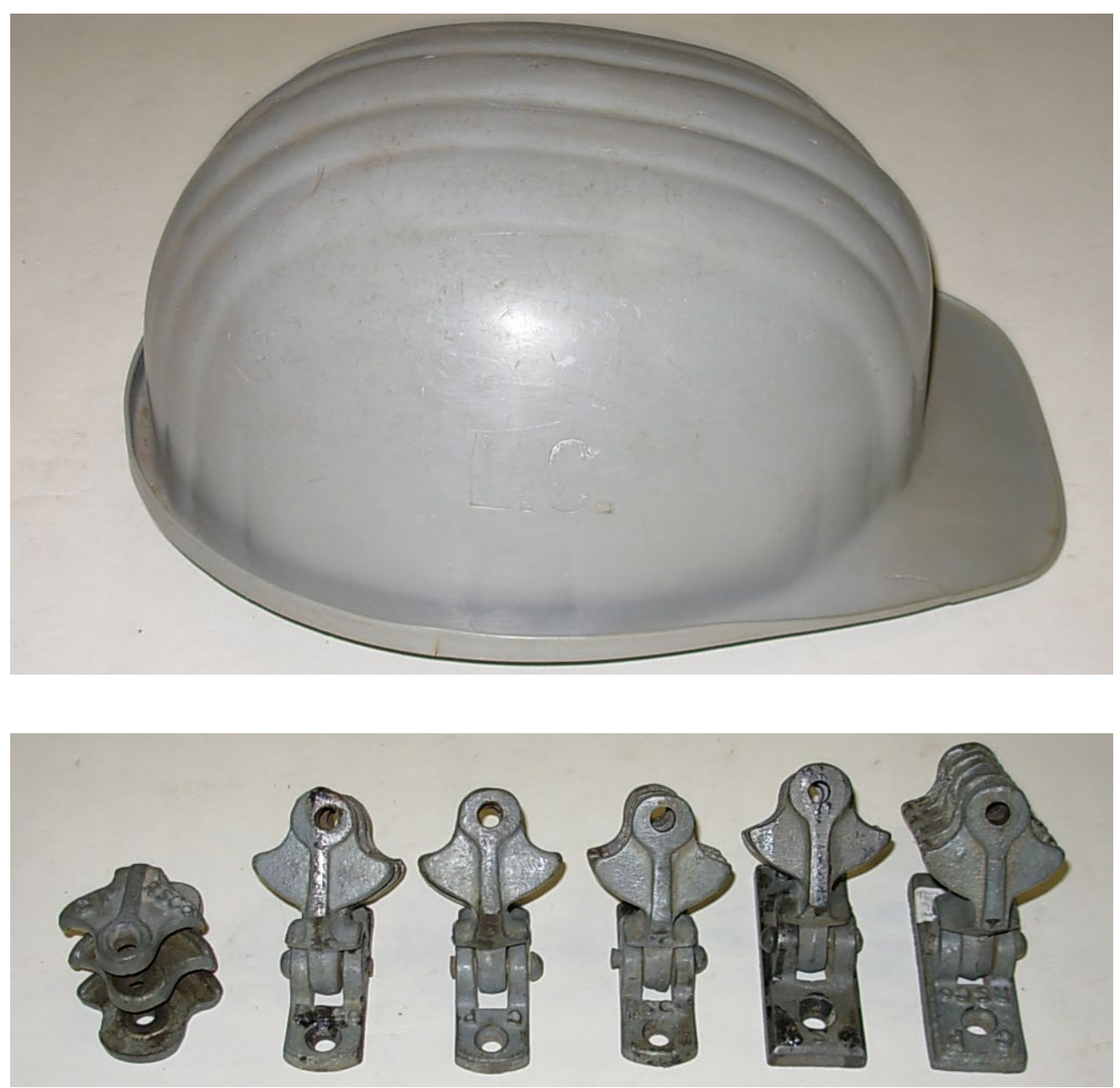


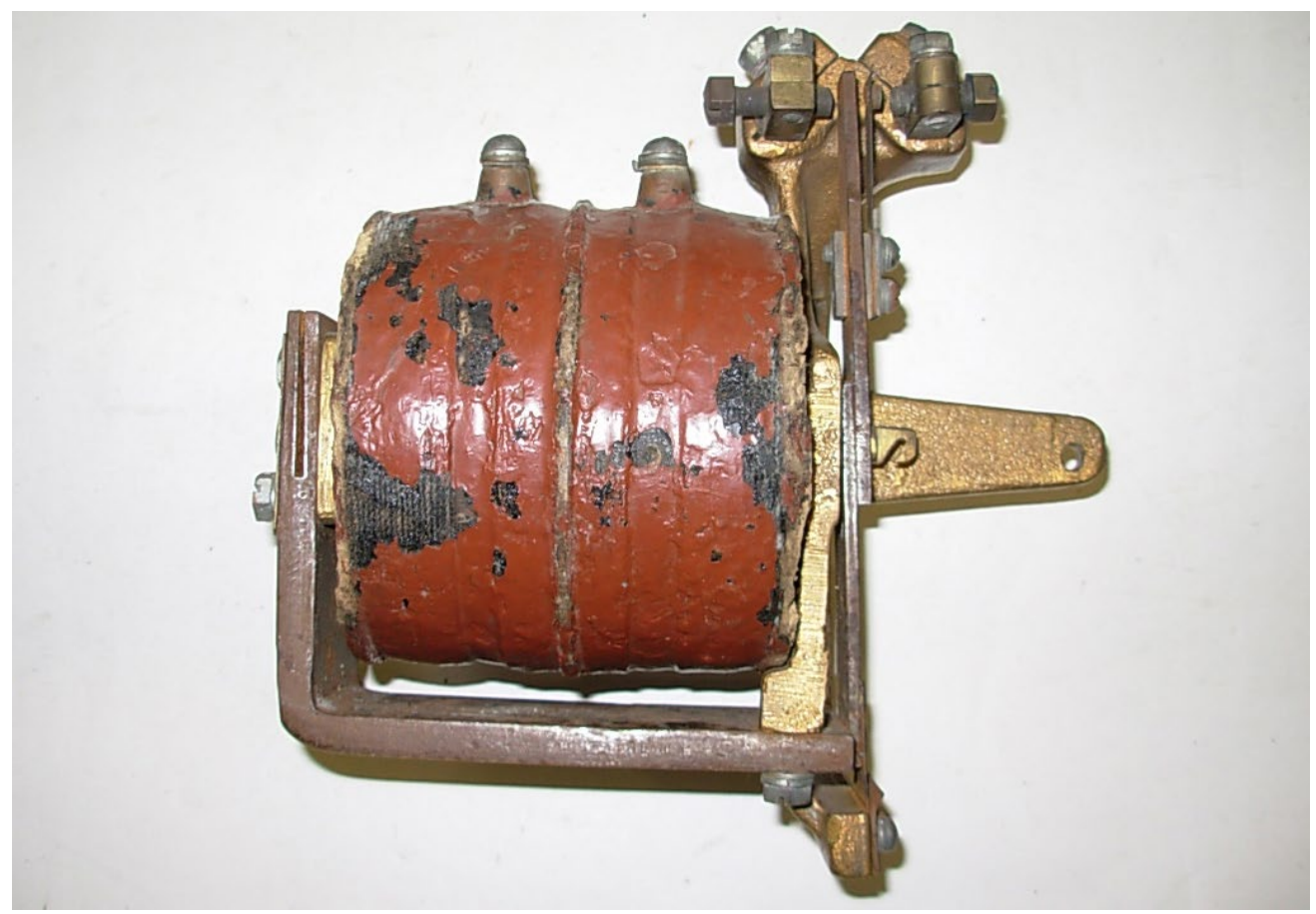

Figura 17 - Relê - interruptor eletromecânico, [s. d.] (Rg: 09999). Coleção Ferroviária. Acervo do Museu Paulista da Universidade de São Paulo. Reprodução: Helio Nobre/José Rosael.

De acordo com Heloisa Barbuy, docente do Museu Paulista, o interesse no referido lote se dá pelas seguintes razões:

Como museu que trata da História da Cultura Material da sociedade brasileira, com especial tônica na História de São Paulo, nossa instituição tem-se empenhado em ampliar sua documentação material, de acordo com suas três linhas de pesquisa - Cotidiano e Sociedade, História do Imaginário e Universo do Trabalho. Dentro desse quadro e perspectiva, alguns eixos relativos ao desenvolvimento do Estado de São Paulo mostram-se de alta relevância, tal o caso da história da expansão cafeeira e de suas representações, relativamente ao qual temos já acervo bastante consistente formado, em boa parte, pelo Dr. Taunay, e que vem sendo estudado pela Profa. Miyoko Makino. Entretanto, no que se refere aos processos de mecanização agrícola e à instalação da ferrovia, ligados à referida expansão cafeeira (e, assim, ao notório desenvolvimento econômico do Estado nas últimas décadas do século XIX e primeiras décadas do século XX), o acervo do Museu Paulista apresenta grandes lacunas. Quanto a implementos agrícolas, a coleção que havia na instituição foi cedida em caráter definitivo, há algumas décadas, para a criação do Museu do Café, em Ribeirão Preto; quanto à história da ferrovia, salvo exceções de objetos comemorativos da inauguração da S. P. Railway (carrinho de pedreiro e pá simbólicos, de jacarandá e prata), nunca antes foi contemplada por trabalhos de pesquisa e coleta de acervos. 
38. Processo $\mathrm{n}^{\circ}$. 2002.1.120.33.6/SVDHICO-MP.
Desse modo, consideramos de todo interesse a coleção de objetos ferroviários ora oferecida ao Museu Paulista, que, caso seja adquirida, virá constituir núcleo documental importante para as pesquisas relativas ao Universo do Trabalho, no âmbito da História de São Paulo, já que a maioria dos objetos que compõem a coleção refere-se à estrutura das ferrovias (elementos que integravam estações e sub-estações), a aspectos técnicos de funcionamento (equipamentos de manutenção e de sinalização) e a sistemas de organização do trabalho (elementos relativos a administração de pessoall), conforme clarificado pela organização elaborada pelo SR. Adilson José de Almeida. ${ }^{38}$

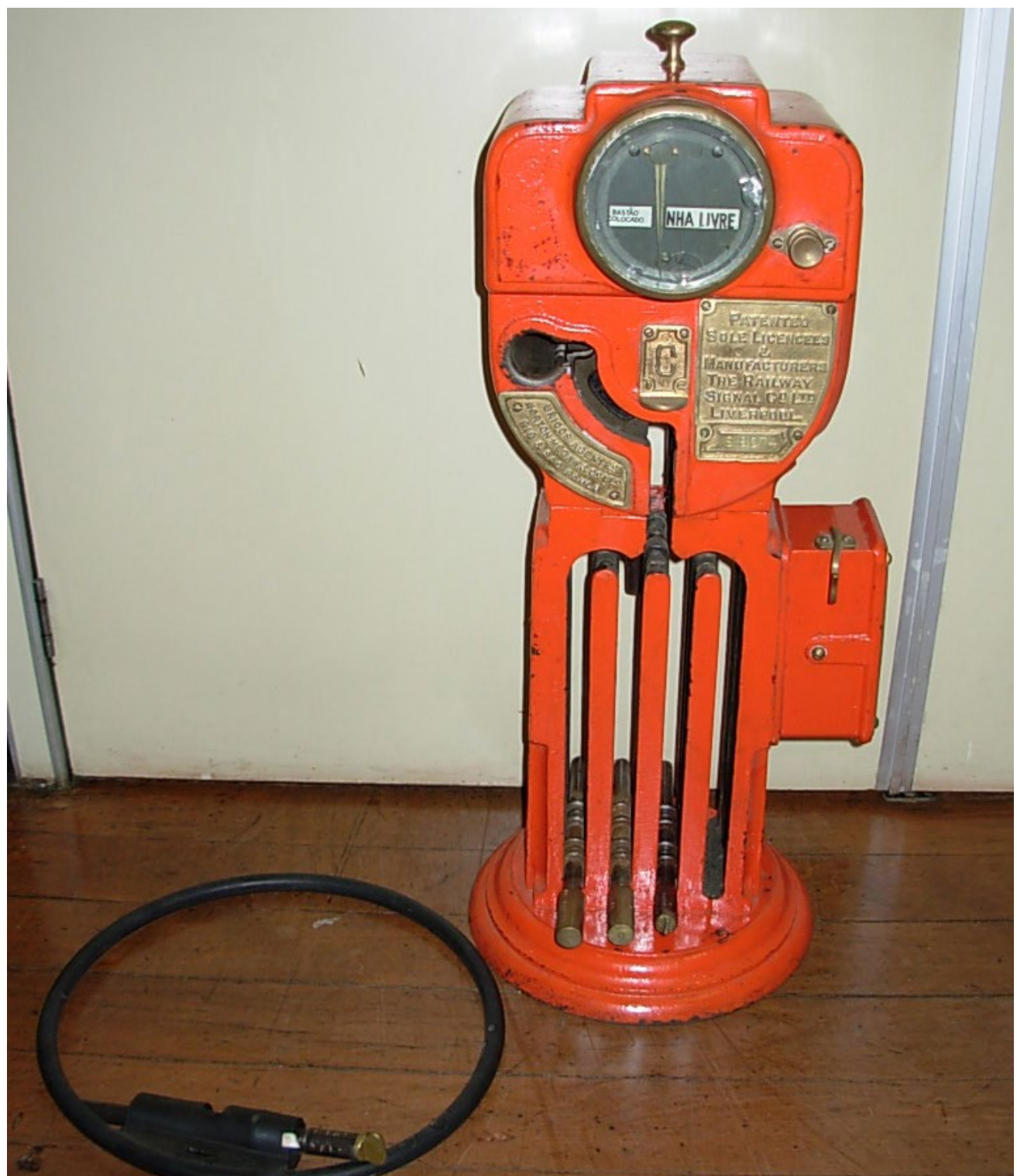

Figura 18 - Staff - equipamento responsável pelo controle de circulação dos trens, [s. d.] (Rg: 09977). Coleção Ferroviária. Acervo do Museu Paulista da Universidade de São Paulo. Reprodução: Helio Nobre/José Rosael. 
Vale a pena destacar o interesse do Museu Paulista, manifestado no trecho acima, em temas clássicos para a história de São Paulo, tais como a expansão cafeeira e o desenvolvimento econômico agrícola. Podemos notar, portanto, que a instituição ao mesmo tempo que se mostra aberta às novas tendências da historiografia também dialoga com temas clássicos relativos ao território paulista.

Por fim, a partir do processo de aquisição acima gostaria de levantar alguns pontos sobre a relação estabelecida entre o Museu Paulista e o mercado de antiquariato. Essa relação efetiva-se tanto por intermédio de transações com lojas de antiquários quanto por profissionais autônomos. Dentre estes últimos, podemos afirmar que Mauricio da Silva Medeiros constitui um dos maiores fornecedores de objetos para o Museu Paulista, por intermédio, em boa parte dos casos, de propostas de venda de coleções à instituição. Durante o período compreendido por esta pesquisa, Medeiros efetuou a venda de 12 conjuntos documentais ao Museu. ${ }^{39}$

Antes de prosseguir, cabe afirmar que a bibliografia nacional e internacional aborda pouco a relação entre museus de história e o mercado de antiguidades, diferentemente do que acontece com relação ao vínculo entre museus e o mercado de arte. Mesmo assim, porém, é importante levantar certos pontos dessa relação no intuito de não a naturalizarmos.

Gostaria, portanto, de salientar o caráter pouco técnico dominante nas ações de valorização e preservação por parte de agentes do antiquariato. Júlia Gonçalves da Silveira ${ }^{40}$, ao abordar práticas comuns no campo do antiquariato, destaca a experiência dos agentes e o caráter pessoal como fundamentais para a prática de comercialização de antiguidades:

As principais fontes de informação, subsidiárias ao trabalho profissional de identificação, seleção e verificação de autenticidade das peças a adquirir, foram discriminadas pela entrevistada, posicionando em primeiro lugar "a prática... é uma coisa que é muito diferente do 'feeling da pessoa'". Ressaltando a dificuldade inerente à essa tare$f a$, citou', em segundo lugar, consultas feitas aos livros especializados $[\ldots]^{41}$

trecho acima deixa explicito o dado de que a experiência do agente é fundamental para as ações de identificação e constatação da autenticidade da peça, sendo que quando o "feeling da pessoa" não for suficiente recorre-se à literatura especializada.

Outro ponto diz respeito à praticamente nula documentação dos itens comercializados. A despeito do fato de que os principais fornecedores de antiguidades para lojas deste ramo serem particulares, "herdeiros de famílias
39. Para acesso aos processos de compra efetuados de Mauricio da Silva Medeiros cf. processos $n^{\circ} 96.1 .340 .33$, 96.1.341.33.6, 97.1.148.33.2, 97.1.201.33.0, 99.1.13.33.1, 99.1.111.33.3, 99.1.370.33.9, 20000.1 .29 .33 .7 , 2002.1 .120 .33 .6 , 2003.1 .113 .33 .0 , 2004.1 .431 .33 .3 , 2005.1 .238 .33 .0 2005.1 .494 .33 .6 , 2005.1 .241 .33 .0 2012.1.146.33.5. Há também referências nos relatórios anuais do MP a outros lotes adquiridos em 2000, 2002, 2006, 2008 e 2009, que por sua descrição não parecem corresponder a nenhum dos processos listados; não há, porém, o número dos respectivos processos nos relatórios citados/SVDHICO-MP.

40. É de fundamental importância lembrar que as reflexões de Silveira foram feitas com base no mercado de antiguidades de Belo Horizonte, que, possivelmente, possui questões específicas devido ao comércio de itens barrocos e de autoria de nomes conhecidos na produção artística nacional.

41. Silveira (2005, p. 234). 
42. Ibid., p. 235.

43. Espig (1998, p. 155).

44. Barros (2011, p. 56).

45. Backzo apud ibid., p. 163.

46. Ibid., p. 163. em processos de inventário", ${ }^{42}$ os fornecedores de antiguidades ao mercado de antiquariato possuem um volume de informação pouco prestigiado pelo mercado, ocasionando, portanto, que a explicitação cabal acerca dos itens comercializados fique à cargo dos agentes comerciais.

Dentre outros aspectos, considero os pontos levantados acima de suma importância para as reflexões empreendidas neste artigo. A documentação e a fidedignidade das informações são essenciais para processos de aquisição de acervo, principalmente quando falamos de instituições públicas e de transações comerciais.

\section{Linha de pesquisa 3: História do Imaginário}

De acordo com Márcia Janete Espig, pode-se conceituar o termo imaginário enquanto "o conjunto mais amplo de representações, imagens e ideias de um determinado grupo social". ${ }^{43}$ José d'Assunção Barros afirma que umas das principais características dos estudos acerca do imaginário é a ênfase em aspectos "que coloquem em cena a mobilidade dos atores, o dinamismo de suas práticas, sua capacidade de desempenharem distintos papéis no mundo cultural". ${ }^{44}$ Tal fato se explica pela intenção dos historiadores ligados a essa temática de pesquisa privilegiarem tanto as percepções sobre as permanências e continuidades - percebidas na longa duração - quanto as mudanças e rupturas práticas e representações sociais.

Outro ponto interessante com relação a essa característica diz respeito à percepção da atuação de agentes com relação ao desenho e à manutenção de "representações, imagens e ideias". A partir do fortalecimento da vertente da história do imaginário, os historiadores começaram a valorizar de forma crescente o que Bronislaw Baczo chamou de "identidade de imaginação", ${ }^{5}$ ou seja, uma forma de pensamento, representação ou imagem social só se estabelece "quando possuir a capacidade de fazer sentido para um determinado grupo social". ${ }^{46}$ Conjuntamente à ação de legitimação propiciada pelos agentes sociais, estes atuam também de maneira decisiva na configuração e reconfiguração de imaginários, abarcando, portanto, o dinamismo entre produtor e receptor de imagens sociais.

As considerações acima nos levam ao primeiro processo de aquisição escolhido para este tópico, de número 2002. 1.287.33.8, referente a aquisição por compra de duas reproduções, em tapeçaria, da pintura Independência ou morte de Pedro Américo (figuras 19, 20 e 21). Tais itens foram adquiridos pela instituição paulista, no ano de 2002, de Luiz Augusto Sorrentini. 


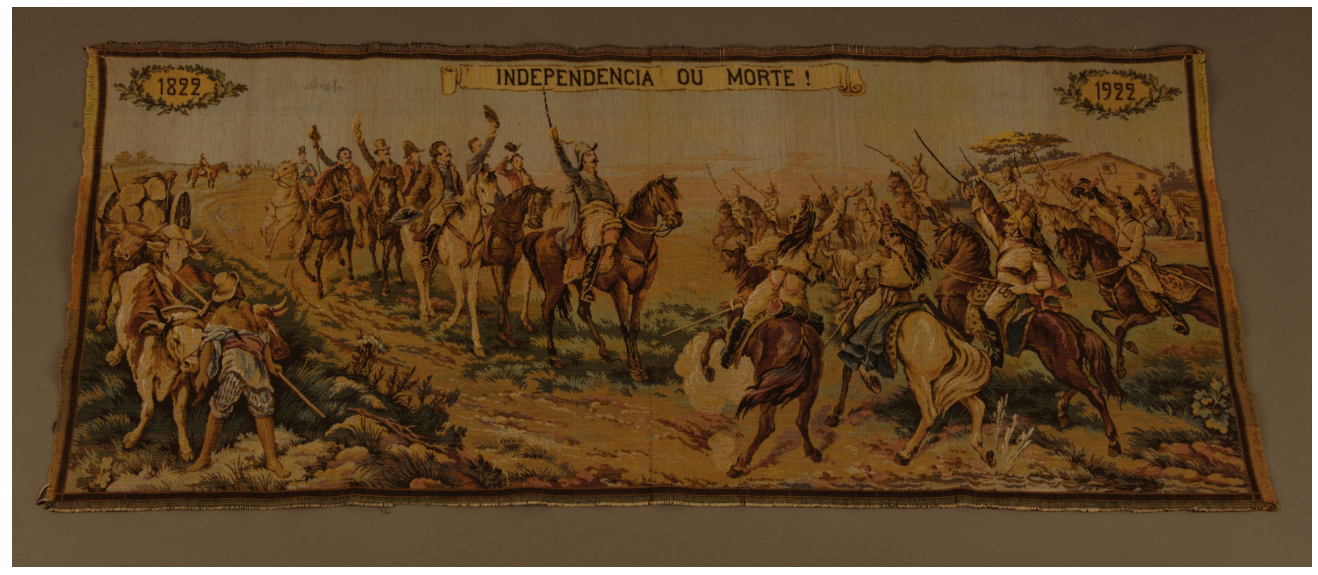

Figura 19 - Tapeçaria com reprodução do painel Independência ou morte, de Pedro Américo [s. d.] (Rg: 10877). Acervo do Museu Paulista da Universidade de São Paulo. Reprodução: Helio Nobre/José Rosael.

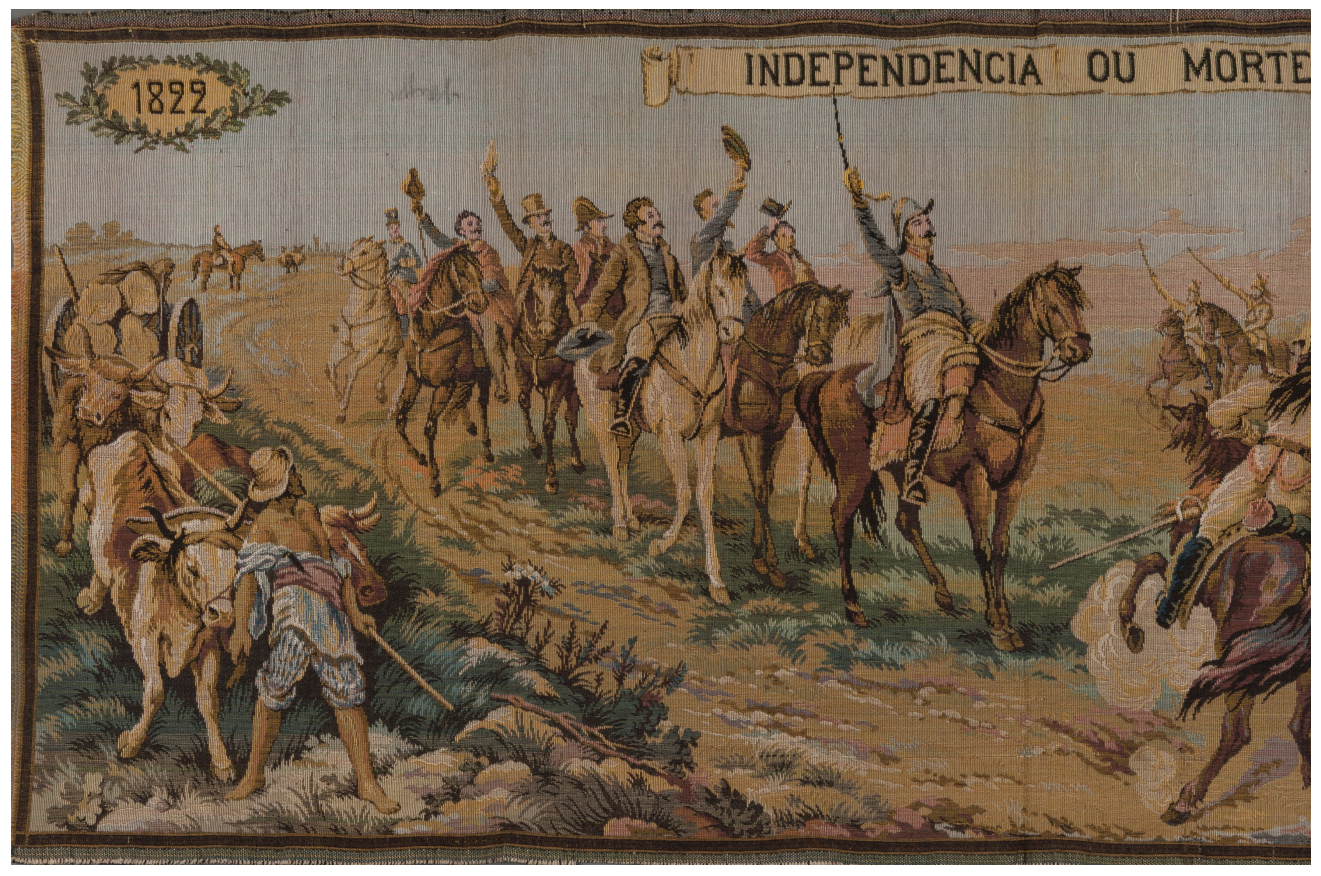

Figura 20 - Detalhe de tapeçaria com reprodução do painel Independência ou morte, de Pedro Américo [s. d.] (Rg: 10877). Acervo do Museu Paulista da Universidade de São Paulo. Reprodução: Helio Nobre/José Rosael. 
47. Processo de doação de Luiz Augusto Sorrenti, de 2002/SVDHICO-MP.

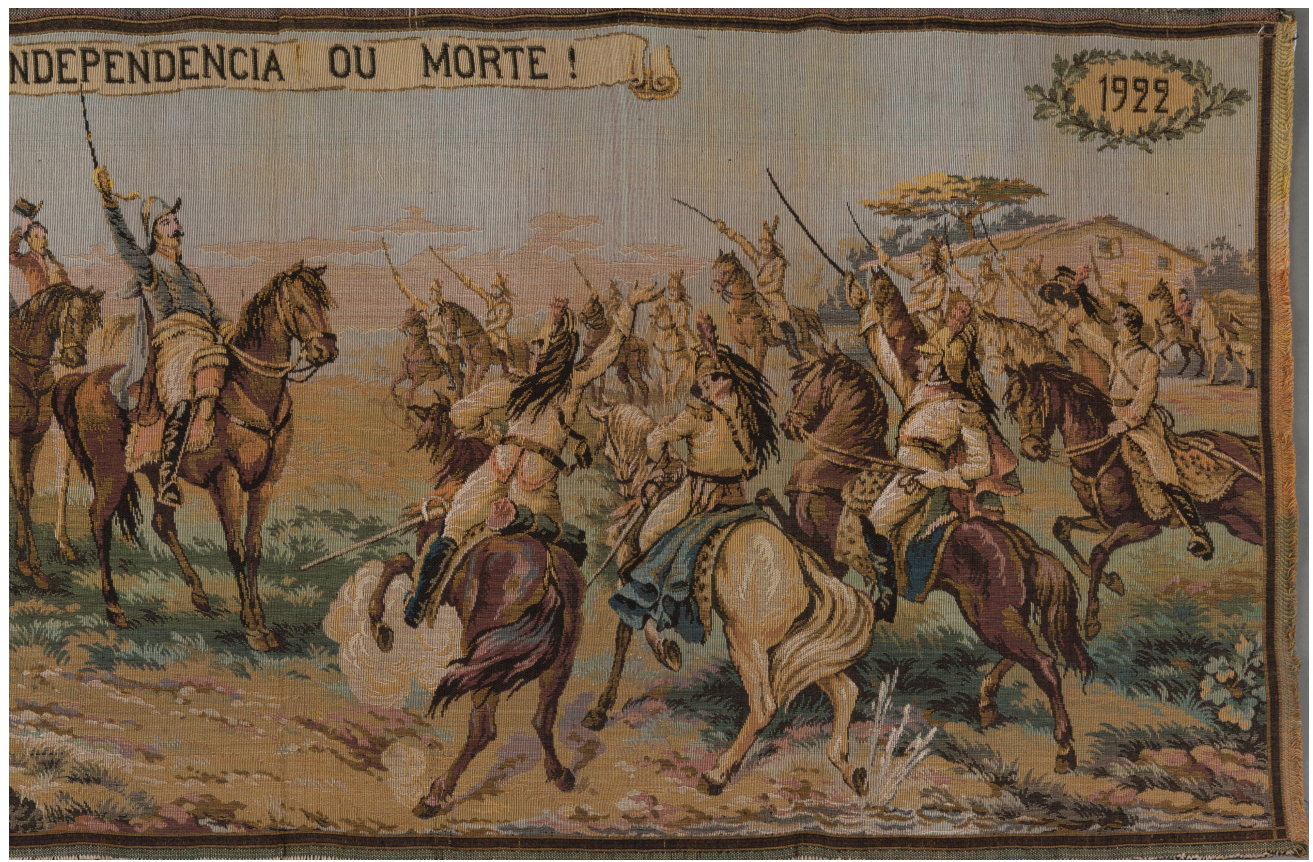

Figura 21 - Detalhe de tapeçaria com reprodução do painel Independência ou morte, de Pedro Américo [s. d.] (Rg: 10877). Acervo do Museu Paulista da Universidade de São Paulo. Reprodução: Helio Nobre/José Rosael.

Segundo a Profa. Dr ${ }^{a}$. Cecília Helena de Salles Oliveira, as peças interessam ao Museu Paulista pelos seguintes motivos:

A aquisição pelo Museu Paulista das duas tapeçarias em questão com reproduções do painel "Independência ou Morte", confeccionado por Pedro Américo, apresentam grande relevância. Além de enriquecerem as coleções relacionadas aos processos de difusão histórica do imaginário sobre o movimento de Independência e a configuração da nação brasileira, as duas peças são particularmente representativas pelas seguintes razões:

a) do ponto de vista técnico, podem ensejar a ampliação e aprofundamento de estudos relacionados à produção e reprodutibilidade de objetos de caráter cultural na sociedade brasileira do início do século XX, inserindo-se nas análises sobre o papel da iconografia na divulgação de noções e representações sobre a identidade nacional.

b) por estarem inscritas nas comemorações do Centenário da Independência, constituem expressões emblemáticas das formas pelas quais, nas diferentes regiões do país, as autoridades públicas buscaram registrar o episódio de 7 de setembro e sua celebração.

c) indicam, por outro lado, que a reprodução em diferentes suportes do painel de Pedro Américo foi feita por meio de apropriações que, muitas vezes, alteraram os traços originais da pintura, como é o caso em questão. ${ }^{47}$ 
A compra destas duas tapeçarias mostra-se interessante, pois exemplifica uma característica fundamental do trabalho institucional desempenhado pelo Museu Paulista: a grande atenção dada às referências culturais relativas ao imaginário da Independência do Brasil. Tal fato se explica por muitas razões.

Primeiramente, o Museu Paulista encontra-se abrigado no edifício-monumento construído em prol das comemorações do Centenário da Independência do Brasil, constituindo, portanto, um dos elementos essenciais na configuração de determinado imaginário social acerca do processo de independência; em segundo lugar, o quadro reproduzido nas tapeçarias adquiridas foi encomendado para figurar no salão de honra do Museu Paulista: contratado em 1886, o artista Pedro Américo de Figueiredo e Mello foi o responsável pela concepção de uma das principais imagens atreladas à história nacional, sendo essa tela já exposta no Museu quando de sua abertura ao público em 1895; terceiro, como o famoso grito de independência foi dado em terras paulistas, esse episódio constituiu, em maior ou menor grau ao longo da história, em importante fator e argumento para a construção de certos discursos relacionados à importância do Estado de São Paulo frente à história nacional; por fim, devemos pontuar que o Museu Paulista, pela sua natureza institucional, atuou como importante vetor no estabelecimento e divulgação de determinadas narrativas com relação à Independência do Brasil.

Sendo assim, é completamente compreensível o interesse da instituição paulista em temáticas tais como o processo de independência por se tratar de assunto fundamental para a compreensão da sociedade brasileira e do percurso institucional. É importante comentar também que o interesse do museu se mostra alinhado às tendências contemporâneas relativas às questões do imaginário, afinal, possui enorme interesse nas diversas apropriações e redefinições feitas, por exemplo, em torno da imagem do grito da Independência, conforme é possível notar a partir de diversos itens do acervo (figuras 22 a 26).

segundo processo a que chamo a atenção refere-se à doação de um expressivo conjunto de fotografias de autoria do famoso fotógrafo oitocentista Militão Augusto de Azevedo. A coleção doada pela Fundação Roberto Marinho e pela Rede Globo constitui-se de aproximadamente 11 mil retratos, 71 álbuns fotográficos, 168 fotografias avulsas (conferir como exemplo as figuras 27 a 30), 40 negativos e manuscritos; faz parte também da coleção três álbuns fotográficos e 37 fotografias avulsas de autoria de Luiz Gonzaga de Azevedo, filho de Militão. ${ }^{48}$

De acordo com a documentação consultada, a aquisição da referida coleção justifica-se por duas principais razões. A primeira relaciona-se ao fato de Militão ser um dos fotógrafos mais importantes para a história da fotografia no Brasil, e, no tocante a São Paulo, ser "o fotógrafo mais importante do século XIX". 49,50
48. Para além da doação de tais itens, o contrato firmado entre as partes abarca o desenvolvimento de um projeto museográfico - em sala específica no prédio do Museu Paulista -, de ações de conservação e preservação dos objetos, exposições temáticas e digitalização das imagens.

49. Processo 96.1.2331.1.0/ SVDHICO-MP.

50. Carvalho e Lima (1997, p. 208), em texto sobre o projeto de aquisição, pesquisa e exposição da coleção Militão, afirmam que "O interesse por objetos de uso simbólico, matéria-prima indispensável nos problemas relativos à história do imaginário e a existência de um núcleo inicial relevante como a pinacoteca do Museu, que reúne retratos e paisagens urbanas, muitas com inspiração fotográfica, foram razões que se somaram ao interesse pela coleção Militão Augusto de Azevedo [...]”. 


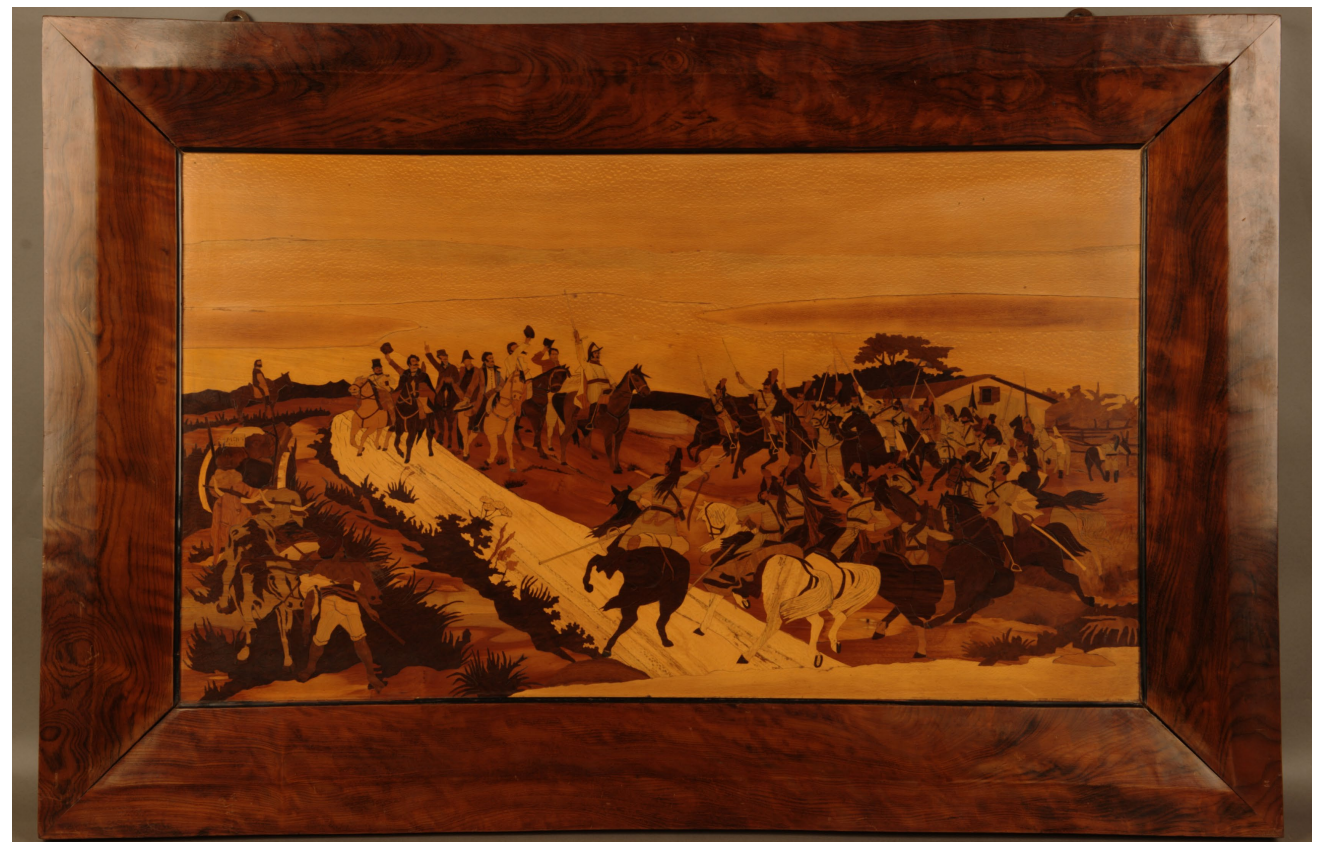

Figura 22 - Marchetaria de madeira com reprodução do painel Independência ou morte, de Pedro Américo [s. d.] (Rg: 06254). Acervo do Museu Paulista da Universidade de São Paulo. Reprodução: Helio Nobre/José Rosael.

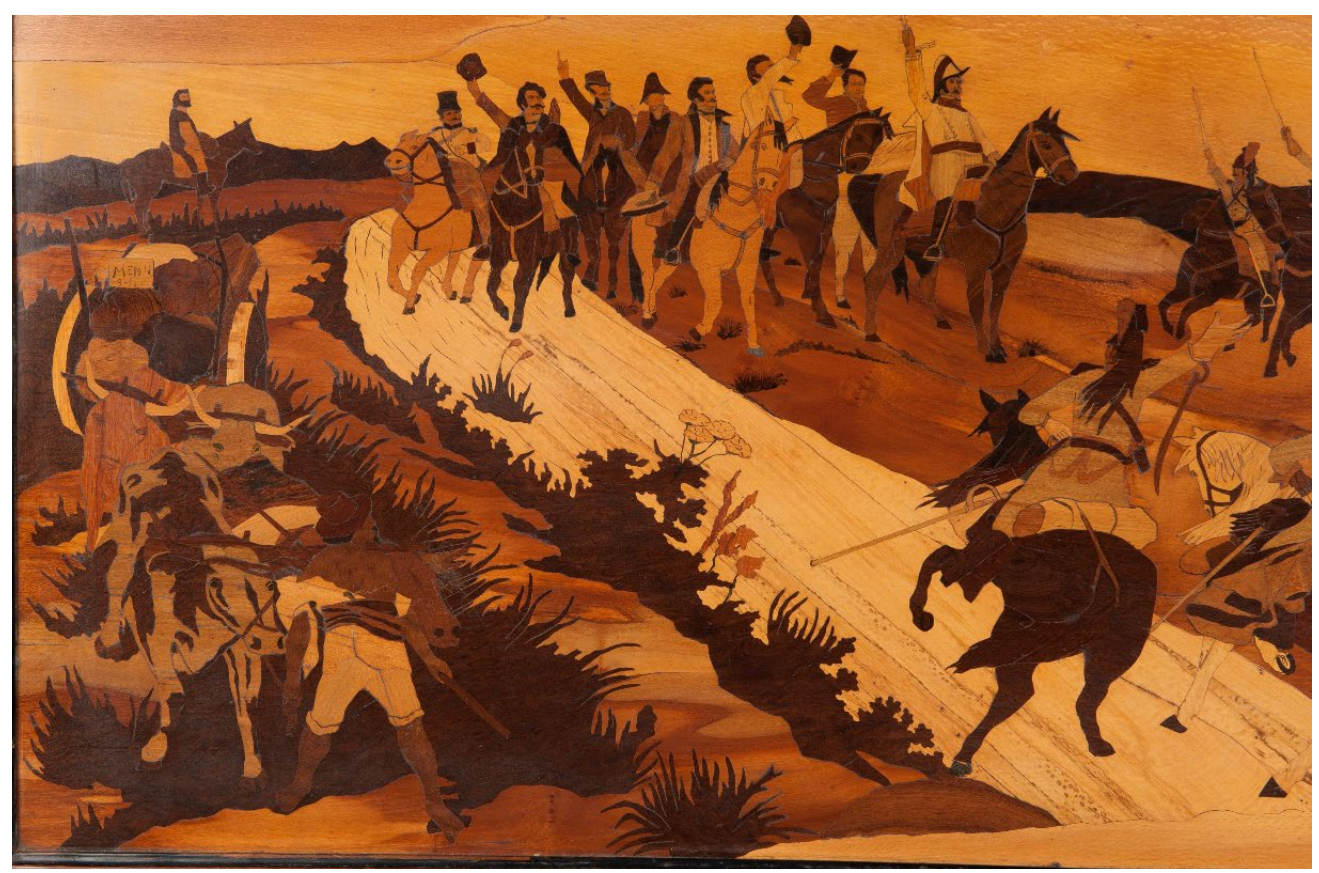

Figura 23 - Detalhe de marchetaria de madeira com reprodução do painel Independência ou morte, de Pedro Américo [s. d.] (Rg: 06254). Acervo do Museu Paulista da Universidade de São Paulo. Reprodução: Helio Nobre/José Rosael. 


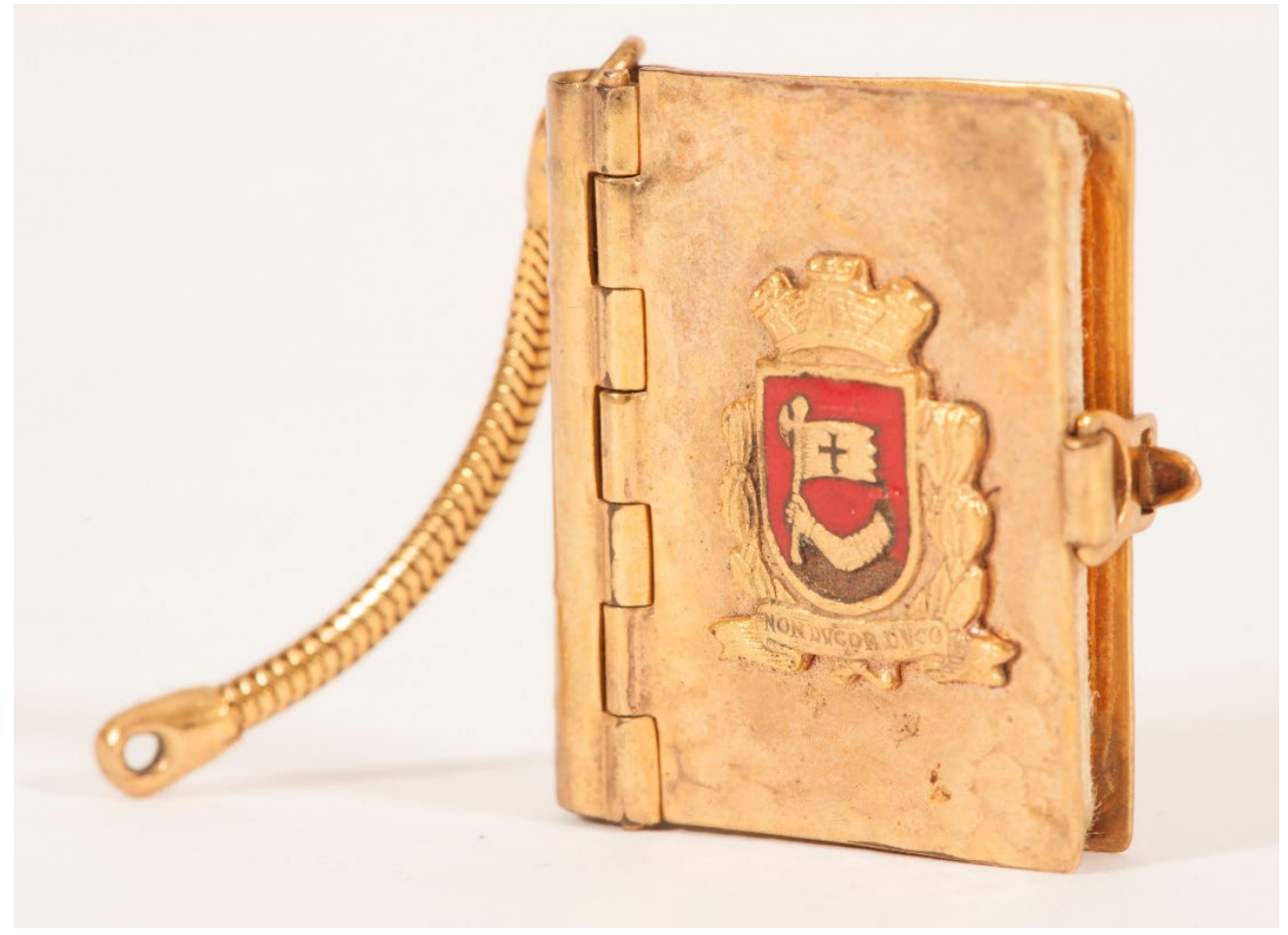

Figura 24 - Chaveiro em forma de livro com brasão da cidade de São Paulo e 15 fotos de monumentos e locais da cidade, 1960 (Rg: 08684). Acervo do Museu Paulista da Universidade de São Paulo. Reprodução: Helio Nobre/José Rosael.

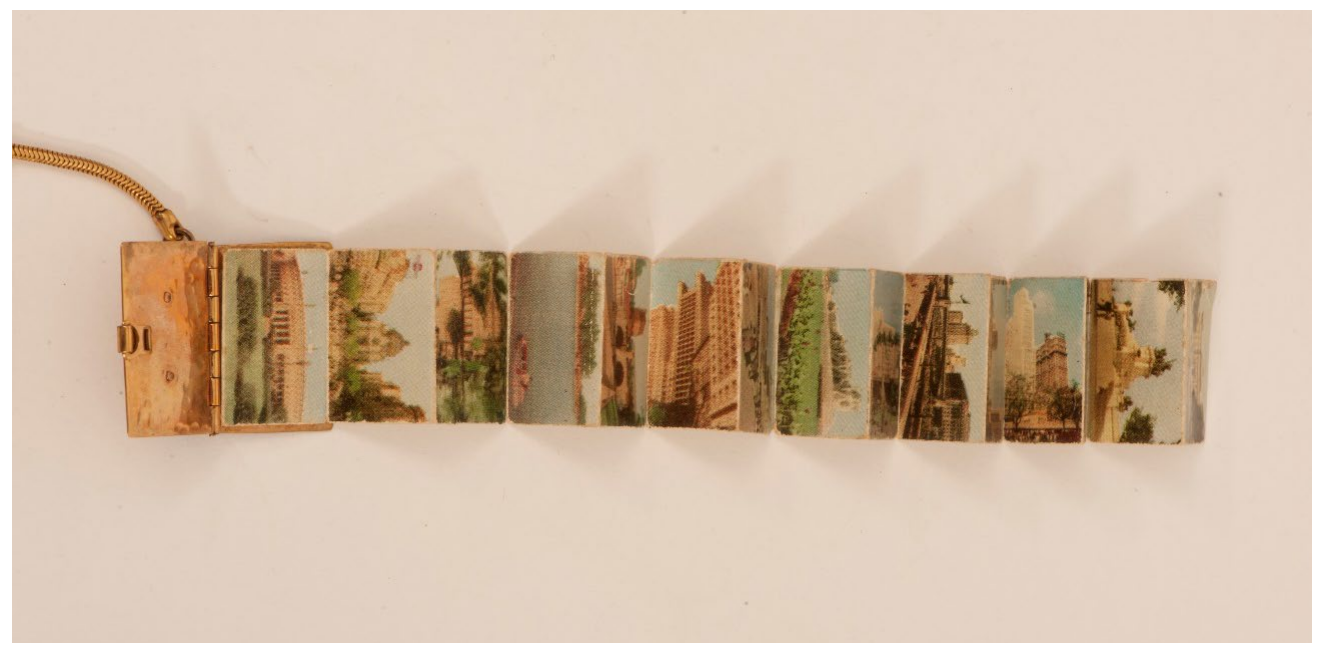

Figura 25 - Chaveiro em forma de livro com brasão da cidade de São Paulo e 15 fotos de monumentos e locais da cidade, 1960 (Rg: 08684). Acervo do Museu Paulista da Universidade de São Paulo. Reprodução: Helio Nobre/José Rosael. 


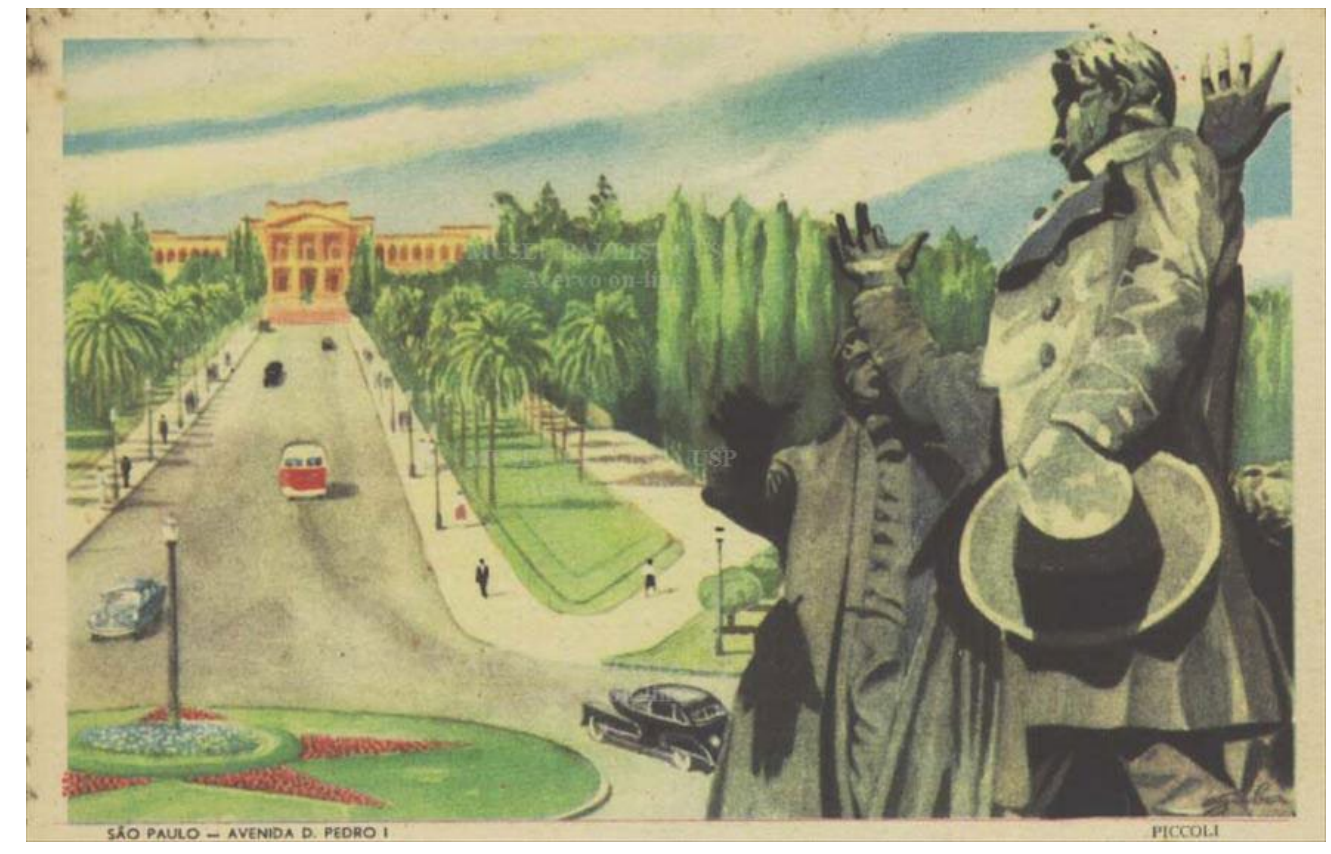

Figura 26 - Cartão-postal "São Paulo - Avenida D. Pedro I" [s. d.] (Rg: 07353). Coleção Rubens Marini. Acervo do Museu Paulista da Universidade de São Paulo. Reprodução: Helio Nobre/José Rosael.

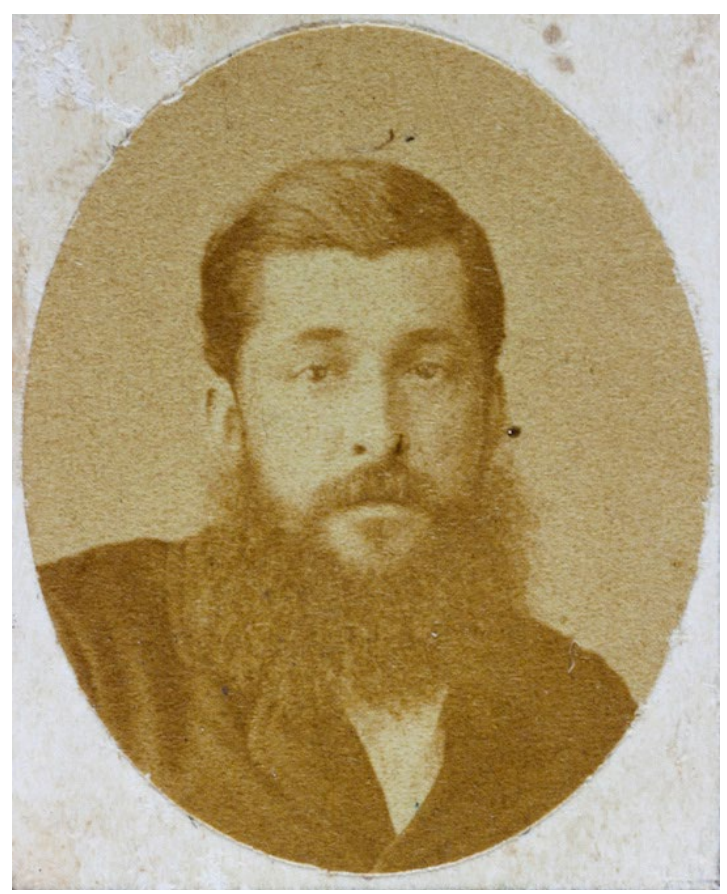

Figura 27 - Retrato masculino. Militão Augusto de Azevedo, 1865-1870 (Rg: 16539). Coleção Militão Augusto de Azevedo. Acervo do Museu Paulista da Universidade de São Paulo. Reprodução: Helio Nobre/José Rosael. 


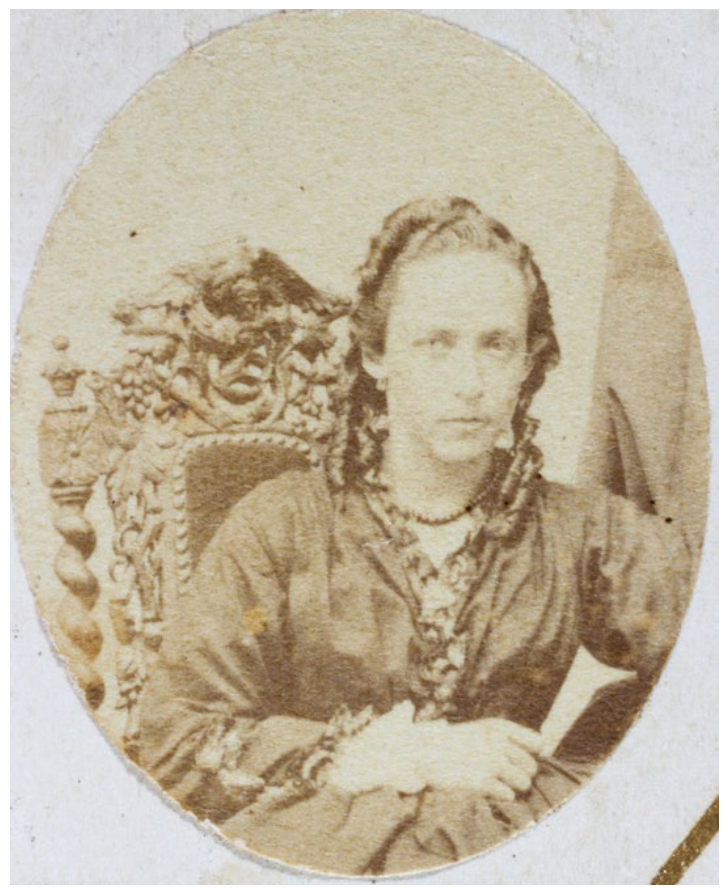

Figura 28 - Retrato feminino. Militão Augusto de Azevedo, 1865-1870 (Rg: 16539). Coleção Militão Augusto de Azevedo. Acervo do Museu Paulista da Universidade de São Paulo. Reprodução: Helio Nobre/José Rosael.

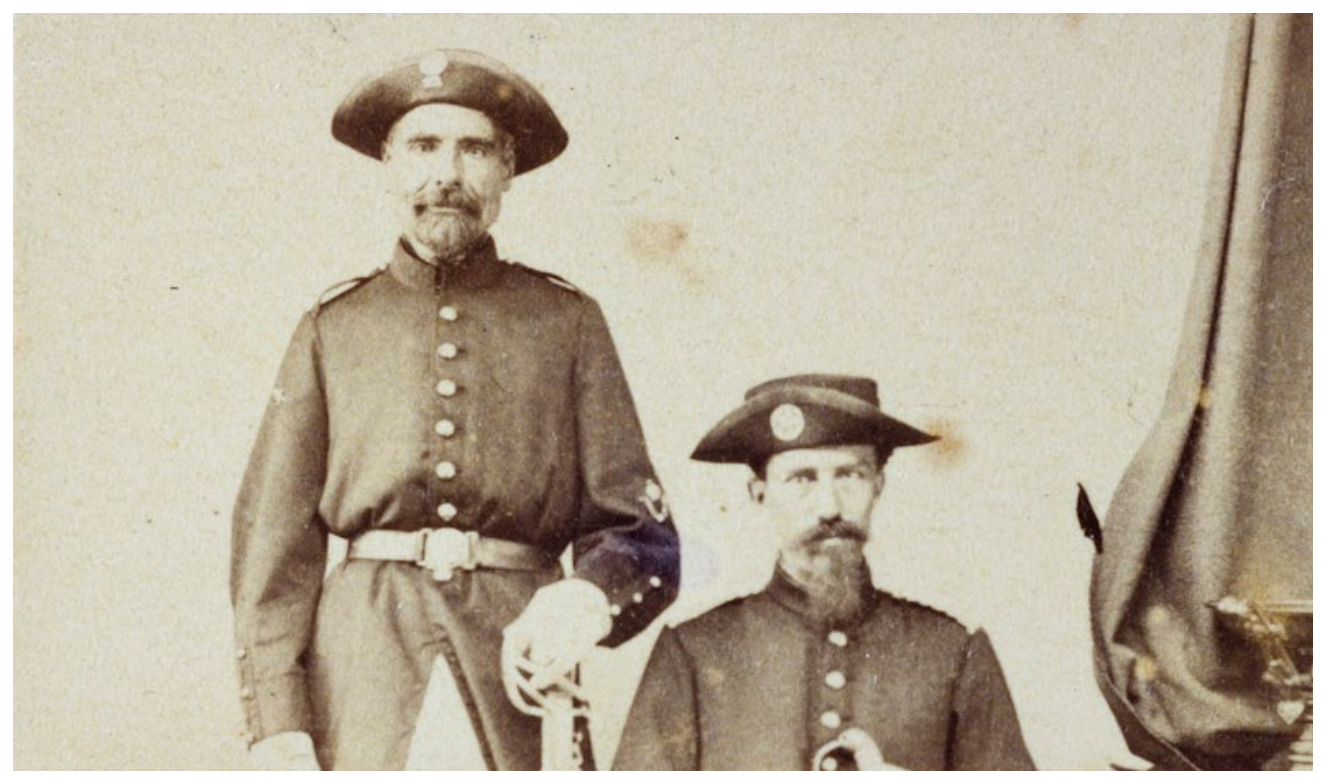

Figura 29 - Retrato de dois oficiais militares. Militão Augusto de Azevedo, 1865-1870 (Rg: 16539). Coleção Militão Augusto de Azevedo. Acervo do Museu Paulista da Universidade de São Paulo. Reprodução: Helio Nobre/José Rosael. 
51. Ibid., p. 209.

52. Processo 96.1.2331.1.0/ SVDHICO-MP.

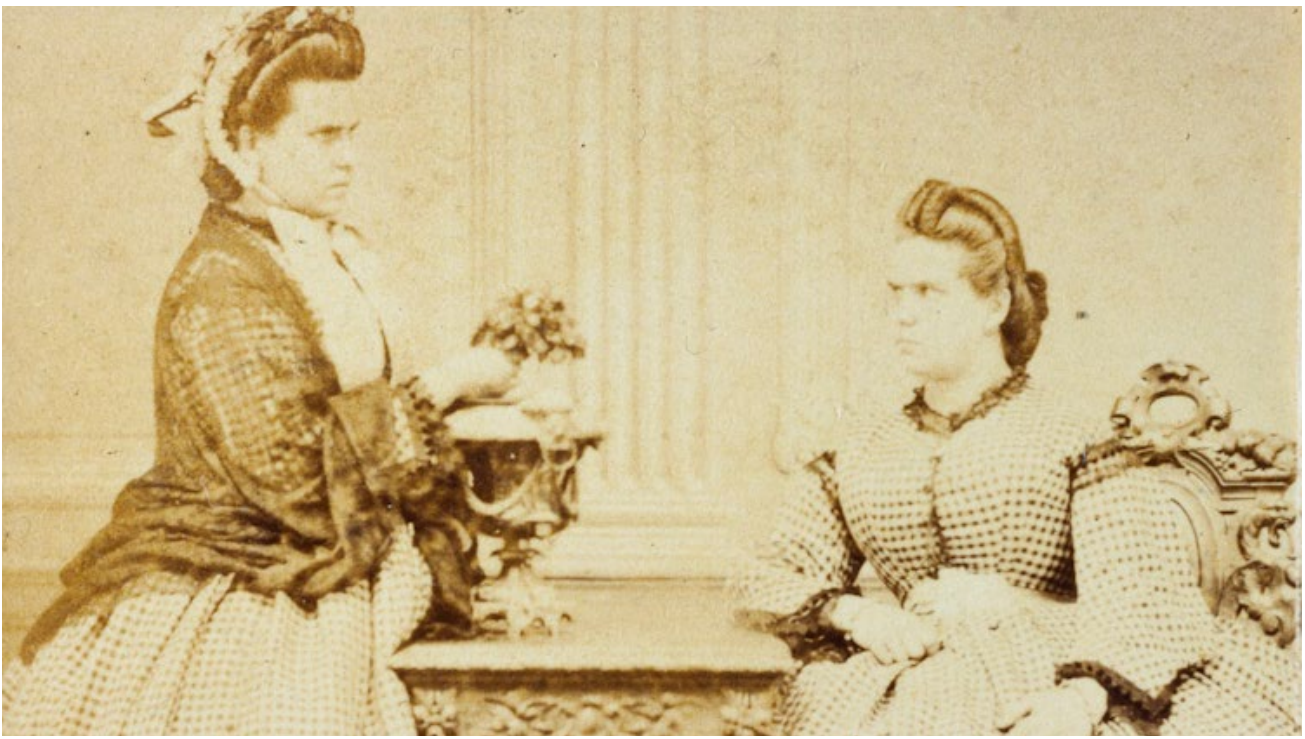

Figura 30 - Retrato de duas mulheres. Militão Augusto de Azevedo, 1865-1870 (Rg: 16539). Coleção Militão Augusto de Azevedo. Acervo do Museu Paulista da Universidade de São Paulo. Reprodução: Helio Nobre/José Rosael.

As docentes Carvalho e Lima realçam também o valor da coleção devido à documentação presente:

Uma das peculiaridades desta coleção, o que a torna mais interessante, é a reunião de documentos que fornecem pistas sobre um circuito de produção, consumo, reciclagem e descarte dos produtos fotográficos [...] As vicissitudes da atividade de um retratista no século XIX estão registradas no livro-copiador de cartas com riqueza de detalhes quanto às relações com fornecedores, estratégias e dificuldades de comercialização de vistas urbanas, o que permite acompanhar a ascensão e declínio do ateliê Photographia Americana. Ainda com base no livro-copiador, é possível datar o uso de materiais e apetrechos fotográficos, distinguindo-se, por exemplo, a introdução de novos métodos e materiais no Brasil com relação à Europa. ${ }^{51}$

Outro ponto interessante a ser levantado refere-se ao fato de que a coleção abarca retratos de personagens das mais variadas camadas sociais da São Paulo do século XIX:

A maior parte das fotografias é constituída por fotos de ateliê e retratos montados pelo próprio autor, para seu arquivo pessoal e que trazem o mais completo e extraordinário registro da população de São Paulo no século passado, abrangendo todos os tipos de personagens: escravos e senhores, negros e pobres, artistas, prostitutas, crianças, velhos, famílias, etc., numa variedade de poses, expressões, indumentárias e adornos, de impressionante riqueza documental. ${ }^{52}$ 
A variedade de personagens retratados é um dos pontos fortes da coleção Militão para o Museu Paulista, afinal contribui para que camadas sociais diferentes sejam objeto da crítica histórica e museológica e vai ao encontro do desejo institucional em ampliar a representação social por meio de seu acervo museológico. Porém, cabe aqui a reflexão acerca do potencial e dos limites desta documentação quando falamos em ampliação das camadas sociais representadas em acervos museológicos: é suficiente empreender essa ampliação apenas do ponto de vista dos retratados? Quais os caminhos para que tal ampliação se dê também nos processos de construção de discursos?

\section{CONSIDERAÇÕES FINAIS}

Quando uma instituição museológica decide musealizar um objeto ou uma coleção, o faz de acordo com critérios intelectuais, políticos e culturais. Há também em jogo, nesse processo, a necessidade de estabelecer filtros que expressem o interesse institucional em determinados temas ou objetos de pesquisa. Sendo assim, o que faz com que uma coleção ou um objeto sejam integrados ao acervo de um museu é sua capacidade de propiciar determinadas induções acerca da cultura material e das relações sociais de uma sociedade, de acordo com as prioridades de cada instituição.

Tais critérios e filtros precisam ser formalmente explicitados em um documento que chamamos de Política de Aquisição de Acervos para que a gestão institucional e a transparência, principalmente em casos de instituições públicas, sejam eficazmente garantidas. Afinal, esse documento, além de constituir um importante instrumento de gestão, trata-se também de um mecanismo de memória institucional.

Para além das questões formais, é fundamental que a execução dessa política seja objeto de interesse de historiadores, museólogos e demais profissionais empenhados com as relações entre o patrimônio cultural e as instituições museológicas. Foi nessa perspectiva que este artigo foi escrito.

A análise da documentação relativa à política e aos processos de aquisição de acervo do Museu Paulista, correspondente aos anos de 1990 e 2015, permite tecer diversos comentários sobre a prática institucional. Essencialmente, deve-se ressaltar o empenho do museu em recolher fontes tridimensionais relativos aos mais diversos grupos sociais, bem como de tipologias extremamente variadas. Tal empenho é indispensável para que o Museu Paulista estabeleça, de forma cada vez mais contundente, relações firmes e solidárias com os variados grupos sociais, 
proporcionando, portanto, o auto reconhecimento destes grupos na instituição e a construção de narrativas de forma cada vez mais colaborativa.

Por fim, é preciso comentar que estamos em um momento ímpar para o levantamento destas questões. A reabertura do Museu Paulista em 2022 exigirá, para além de reestruturações físicas no edifício, reformulações conceituais para a prática institucional, levando o museu a corresponder às demandas políticocríticas, culturais e sociais direcionadas aos espaços museológicos. 


\section{REFERÊNCIAS}

FONTES IMPRESSAS

MENESES, Ulpiano Toledo Bezerra de. Plano Diretor do Museu Paulista da USP. São Paulo, Museu Paulista, 1990.

MENESES, Ulpiano Toledo Bezerra de. Museu e pesquisa: pontos básicos para uma reflexão preliminar. São Paulo, Museu Paulista, 1989.

MENESES, Ulpiano Toledo Bezerra de. Plano Diretor do Museu Paulista da USP. São Paulo, Museu Paulista,1990a.

MENESES, Ulpiano Toledo Bezerra de. Novos rumos para o Museu Paulista. Diretrizes para implantação imediata de um museu histórico. São Paulo, Museu Paulista, 1990b.

MUSEU PAULISTA - Serviço de Documentação Textual e Iconografia (SVDHICO-MP).

LIVROS, ARTIGOS E TESES

ALMEIDA, Maria Mota. Mudanças Sociais/Mudanças Museais, Nova Museologia/Nova História - Que relação?. Cadernos de Sociomuseologia, [s. l.], v.5, n. 5, jun. 1996. Disponível em: $<$ http://bit.ly/2RGYy8p>. Acesso em: 30 maio 2018.

ALVES, Ana Maria de Alencar. O Ipiranga apropriado: ciência, política e poder. O Museu Paulista, 1893-1922. São Paulo: Humanitas/FFLCH/USP, 2001.

BAPTISTA, Jean.; BOITA, Tony. Memória e esquecimento LGBT nos museus, patrimônios e espaços de memória no Brasil. Revista do Centro de Pesquisa e Formação SESC, v. 5, p. 108119, 2017. Disponível em: <http://bit.ly/356jFVq>. Acesso em: maio 2018.

BARBUY, Heloisa.; ORNSTEIN, S.heila Walbe. Museu Paulista: Contribuições Acadêmicas e Políticas Públicas. In: GOLDEMBERG, J. (Ccoord). USP 80 anos. São Paulo, Edusp, 2015.

BARROS, José Costa d'Assunção. A Escola dos Annales: considerações sobre a História do Movimento. Revista Eletrônica História em Reflexão, v. 4, n. 8, 2010. Disponível em: <http://bit.ly/2RAZ5bV>. Acesso em: 30 maio 2018. 
BARROS, José Costa d'Assunção. A História Social: seus significados e seus caminhos. LPH-Revista de História, p. 14-15, 2005. Disponível em: <http://bit.ly/2E21qo5>. Acesso em: 30 maio 2018.

BARROS, José Costa d'Assunção. A Nova História Cultural - considerações sobre o seu universo conceitual e seus diálogos com outros campos históricos. In: Cadernos de História, v.12, $\mathrm{n}^{\circ}$ 16, 2011, p. 38-63. Disponível em: <http://bit.ly/2RA8FM1>. Acesso em: maio 2018.

BONFIM, Paulo. Ricardo. O cotidiano na nouvelle histoire: um campo de investigação fértil de "outras histórias". Revista Científica e-Locução, v. 1, n. 3, 2015. Disponível em: <http:// bit.ly/2sU6J6G>. Acesso em: 30 maio 2018.

BREFE, Ana. Claudia. Fonseca. O Museu Paulista: Affonso de Taunay e a memória nacional, 1917-1945. São Paulo: Editora UNESP/Museu Paulista, 2005.

BURKE, Peter. (Org.). A Escrita da História: novas perspectivas. São Paulo: Fundação Editora da UNESP, 1992, $13^{\circ}$ edição.

CARDOSO, Ciro Flamarion; VAINFAS, Ronaldo. Domínios da história. Rio de Janeiro: Campus, v. 997, 1997.

CARVAlHO, Vânia. Carneiro; LIMA, Solange. Ferraz. de. Fotografia no Museu: o projeto de curadoria da Coleção Militão Augusto de Azevedo. Anais do Museu Paulista Revista de História e Cultura Material, Nova Série, São Paulo, v. 5, p. 205-245, 1997. Disponível em: $<$ http://bit.ly/2ruwA4W>. Acesso em: 30 maio 2018.

CHALHOUB, Sidney; SILVA, Fernando Teixeira da. Sujeitos no imaginário acadêmico: escravos e trabalhadores na historiografia brasileira desde os anos 1980. Cadernos AEL, vol. 14, n. 26, 2009, p. 13-45. Disponível em: <https://www.ifch.unicamp.br/ojs/index. php/ael/article/viewFile/2558/1968>. Acesso em: maio 2018.

CURY, Marília. Xavier. Museologia. Marcos referenciais. Cadernos do CEOM, Chapecó, n. 21, p. 45-73, 2005. Disponível em: <http://bit.ly/2YCXvYn>. Acesso em: maio 2018.

ESPIG, Márcia. Janete. Ideologia, mentalidades e imaginário: cruzamentos e aproximações teóricas. Anos 90, Porto Alegre, n. 10, p. 151-167, 1998. Disponível em: <http://bit. ly/340URwN>. Acesso em: maio 2018.

JUCÁ, Ana Lúcia Almeida de Oliveira; LOPES, Arzelinda Maria A. M. A vida numa vila operária. Informativo Arquivo Histórico Municipal, 4 (19): jul/ago, 2008. 
MAKINO, Miyoko; SILVA, Shirley Ribeiro da; LIMA, Solange Ferraz de; CARVALHO, Vânia Carneiro de. O Serviço de documentação textual e iconografia do Museu Paulista. Anais do Museu Paulista, São Paulo, v. 10-11, n. 1, p. 259-304, 2003. Disponível em: <http://bit. ly/2qGfReE>. Acesso em: maio 2018.

MATIAS, Lilian de Souza Lima. Reflexões sobre os caminhos da história social do trabalho e o conceito de classe trabalhadora. Espaço Plural, v. 17, n. 34, p. 37-55, 2016. Disponível em: <http://bit.ly/2rl3eWM>. Acesso em: maio 2018.

MORANGUEIRA, Vanderlice de Souza. Vila Maria Zélia: visões de uma vila operária em São Paulo. 2006. Dissertação (Mestrado em História Econômica) - Faculdade de Filosofia, Letras e Ciências Humanas, Universidade de São Paulo, São Paulo, 2006.

PADILHA, Renata Cardozo. Documentação museológica e gestão de acervo. Florianópolis: FCC, 2014.

PAUlA, Teresa Cristina Toledo de. Tecidos no museu: argumentos para uma história das práticas curatoriais no Brasil. Anais do Museu Paulista, São Paulo, v. 14, n. 2, p. 253-298, dez. 2006. Disponível em: <https://bit.ly/2UqG9x9>. Acesso em: 28 mar. 2018.

SILVEIRA, Júlia Gonçalves da. Antiquários: um olhar sobre seu trabalho e comportamento informacional. Perspect. Ciênc. Inf., Belo Horizonte, v. 10 n. 2, p. 220-239, jul./dez. 2005. Disponível em: <http://bit.ly/2ruw1YS>. Acesso em: 30 maio 2018.

SOUZA, Eloisio Moulin de; CARRIERI, Alexandre de Pádua. A analítica queer e seu rompimento com a concepção binária de gênero. Revista de Administração Mackenzie, v. 11, n. 3, p. 46-70, 2010. Disponível em: <http://bit.ly/2LzY0x2>. Acesso em: 30 maio 2018.

SOUZA, Flavia Fernandes de. Trabalho doméstico: considerações sobre um tema recente de estudos na História Social do Trabalho no Brasil In. Revista Mundos do Trabalbo, v. 7 n. 13. p. 275-296, jan.-jun. 2015. Disponível em: <http://bit.ly/2LD1oai>. Acesso em: 30 maio 2018.

VIEIRA, Leonardo da Silva. Apontamentos acerca da política de aquisição de acervo no Museu Paulista (1990-2015). 2018. Dissertação (Mestrado em Museologia) - Universidade de São Paulo, São Paulo, 2018.

Artigo apresentado em 11/12/2019. Aprovado em 1 1/5/2020. (cc) BY 